2. To: (Receiving Organization)

Distribution

5. Proj./Prog./Dept./Div.:

Spent Nuclear Fuel Project

8. Originator Remarks:

SNFP Technical Databook Submittal

3. From: (Originating Organization)

SNF Characterization Project

6. Design Authority/ Design Agent/Cog. Engr.:

D.J. Trimble

4. Related EDT No.:

7. Purchase order No.:

$N / A$

9. Equip./Component No.:

$\mathrm{N} / \mathrm{A}$

10. System/Bldg./Facility:

$N / A$

11. Receiver Remarks: - 11A. Design Baselịne Document? [ ] Yes [X] No

12. Major Assm. DWg. No.:

N/A

13. Permit/Permit Application No.: $\mathrm{N} / \mathrm{A}$

14:-Required-Response Date:

$\mathrm{N} / \mathrm{A}$

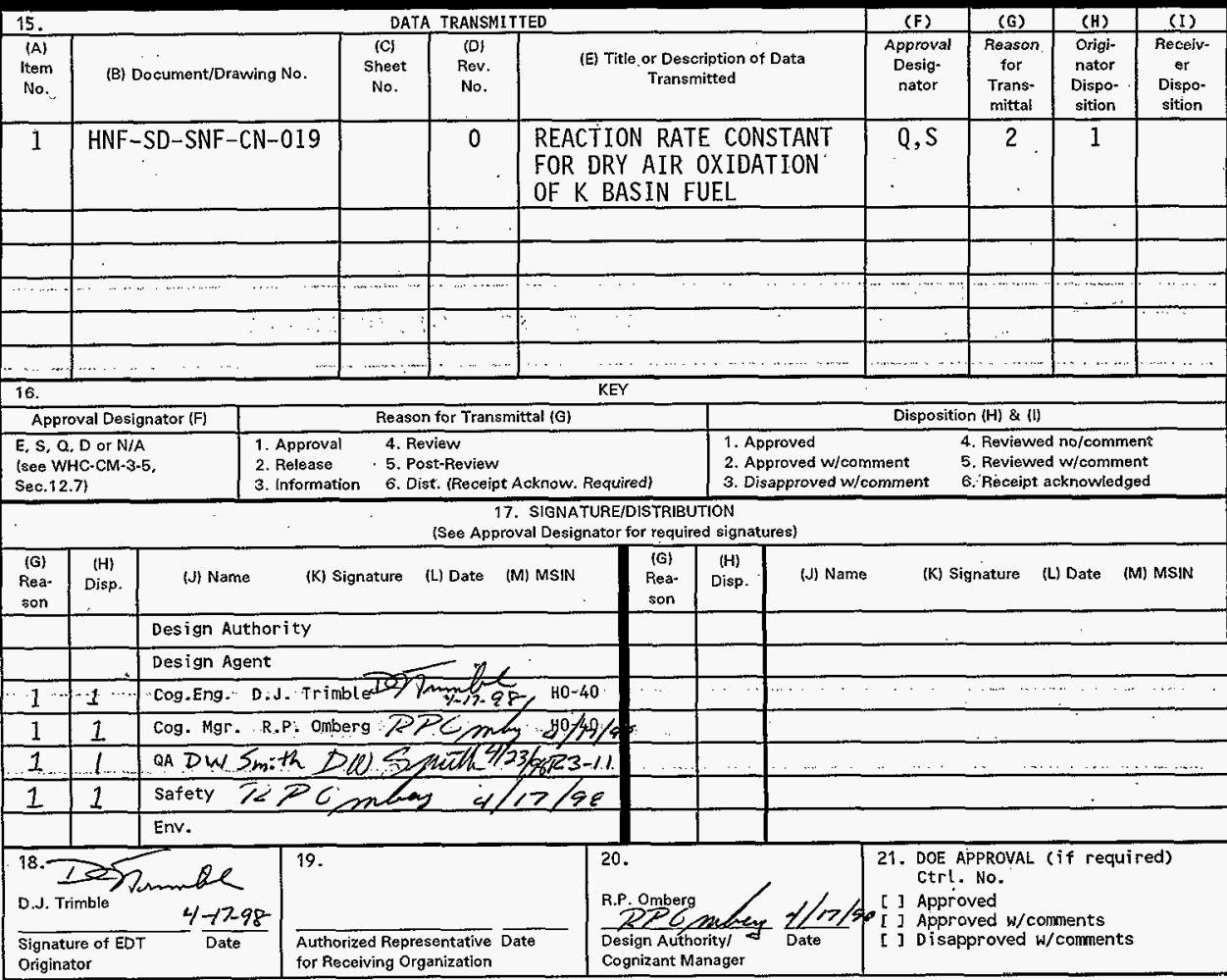




\section{REACTION RATE CONSTANT FOR DRY AIR OXIDATION OF K BASIN FUEL}

D. J. Trimble

Duke Engineering \& Services Hanford, Inc., Richland, WA 99352

U.S. Department of Energy Contract DE-ACO6-96RL13200

EDT/ECN: 620809

UC: 2070

Org Code: 2T720

Charge Code: LB072 (HAN67700)

B\&R Code: EW7040000

Total Pages: 44

Key Words: Spent Nuclear Fuel, Oxidation, K Basin, N Reactor Fuel, Uranium

Abstract: The rate of oxidation of spent nuclear fuel stored in the $\mathrm{K}$ Basin water is an important parameter when assessing the processes and accident scenarios for preparing the fuel for dry storage. The literature provides data and rate laws for the oxidation of unirradiated uranium in various environments. Measurement data for the dry air oxidation of $\mathrm{K}$ Basin fuel is compared to the literature data for linear oxidation in dry air. Equations for the correlations and statistical bounds to the $K$ Basin fuel data and the literature data are selected for predicting nominal and bounding rates for the dry air oxidation of the $\mathrm{K}$ Basin fuel. These rate equations are intended for use in the Spent Nuclear Fuel Project Technical Databook.

TRADEMARK DISCLAIMER. Reference herein to any specific commercial product, process, or service by trade name, trademark, manufacturer, or otherwise, does not necessarily constitute or imply its endorsement, recommendation, or favoring by the United States Government or any agency thereof or its contractors or subcontractors.

Printed in the United States of America. To obtain copies of this document, contact: Document Control services, P.O. Box 950, Mailstop H6-08, Richland WA 99352, Phone (509) 372-2420;

Fax (509) 376-4989.
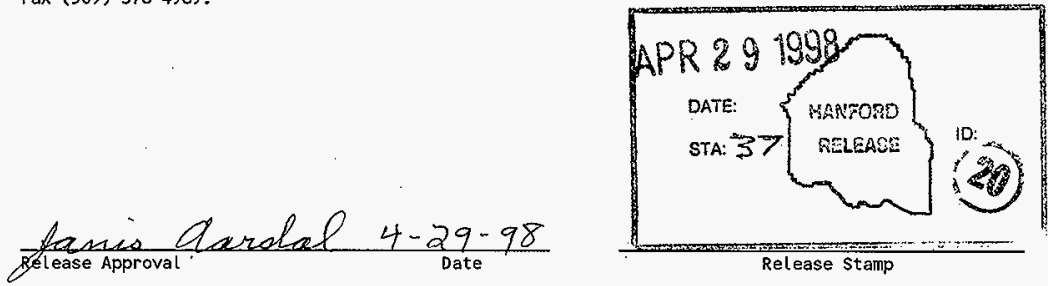


\section{Title: Reaction Rate Constant for Dry Air Oxidation of K Basin Fuel}

Description: Reaction rate constant for dry air oxidation of $\mathrm{K}$ Basin fuel for process and safety calculations.

Originators:

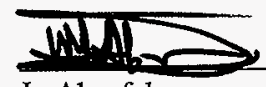

J. Abrefah

Pacific Northwest National

Laboratory

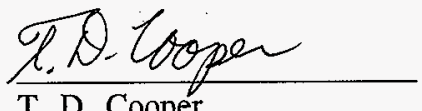

T. D. Cooper

B\&W Hanford Company

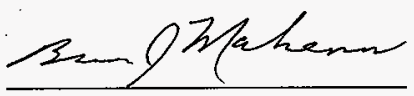

B. J. Makenas

DE\&S Hanford, Inc.

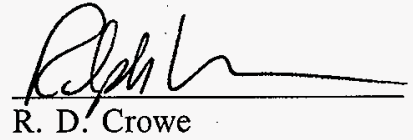

Fluor Daniel Northwest

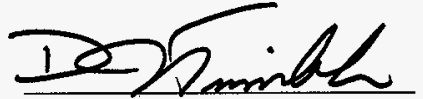

D. J. Trimble

DE\&S Hanford, Inc.

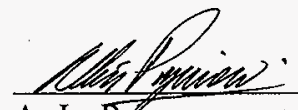

A. L. Pajunen

SGN Eurisys Services

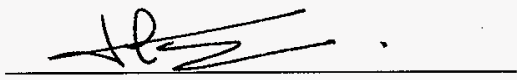

T. A. Flament

Numatec Hanford Corporation Corp. 
HNF-SD-SNF-CN-019, Rev. 0

\section{CONTENTS}

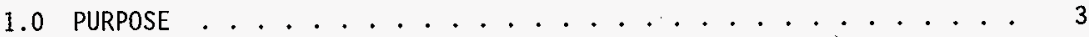

2.0 SUMMARY STATEMENT OF PARAMETER . . . . . . . . . . 3

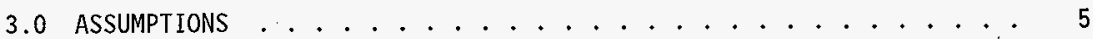

4.0 SOURCES OF INFORMATION ..................... 5

5.0 REACTION RATES ........................ 6

5.1 DEFINITION OF TERMS .................. 6

5.2 AIR OXIDATION OF URANIUM . . . . . . . . . . 7

5.3 LITERATURE DATA BASE FOR ANALYSIS . . . . . . . . . . . 8

5.4 REGRESSION ANALYSIS OF LITERATURE DATA .......... 8

5.5 COMPARISON TO FRENCH AND ENGLISH URANIUM DATA . . . . . . 10

5.5.1 Comparison to Unirradiated Uranium Data ....... 10

5.5.2 Comparison to Irradiated Uranium Data. . . . . . . 13

5.6 COMPARISON TO K BASIN FUEL DATA . . . . . . . . . 13

$5.6 .1 \mathrm{~K}$ Basin Fuel Data Analysis . . . . . . . . . . . . 13

5.6.2 Uncertainty in Spent Nuclear Fuel Data . . . . . . . . 16

5.7 RECOMMENDED REACTION RATE EQUATIONS . . . . . . . . 16

5.8 ENHANCEMENT FACTOR . . . . . . . . . . . . . . 18

5.9 OXIDATION OF CLEAN SURFACES .............. 18

6.0 REFERENCES . . . . . . . . . . . . . . . . 20

APPENDIX A DATA BASE FOR DRY AIR OXIDATION OF UNIRRADIATED

URANIUM . . . . . . . . . . . . . . 23

$\begin{array}{lll}\text { APPENDIX B } & \text { SUPPLEMENTAL FRENCH AND ENGLISH DATA FOR DRY AIR } \\ & \text { OXIDATION OF URANIUM . . . . . . . . . . . . } 31\end{array}$

APPENDIX $C \quad K$ BASIN FUEL DATA FOR DRY AIR OXIDATION . . . . . . 35

APPENDIX D NON-LINEAR OXIDATION ............. 37 
HNF-SD-SNF-CN-019, Rev. 0

\section{LIST OF FIGURES}

1. Data Base for Oxidation Rate of Uranium in Dry Air........ 9

2. Comparison of the Pearce Equations and the Regression Analysis of the Literature Data for Oxidation of Uranium in Dry Air . . . . 11

3. Comparison of Regression Analysis for Dry Air Oxidation of Uranium with French and English Data for (a) Unirradiated Uranium and (b) Irradiated Uranium ............. 12

4. K Basin Fuel Dry Air Oxidation Data and Analysis . . . . . . . . 15

5. Comparison of Data Base and Regression Analysis for Dry Air Oxidation of Uranium with K Basin Fuel Data . . . . . . . 17

6. Graphical Representation of the Recommended Reaction Rate Equations for K Basin Fue in Dry Air . . . . . . . . 19 
HNF-SD-SNF-CN-019, Rev. 0

\section{REACTION RATE CONSTANT FOR DRY AIR OXIDATION OF K BASIN FUEL}

\subsection{PURPOSE}

The purpose of the calculations outlined here is to update the equations for the reaction rate constant for dry air oxidation of the irradiated $N$ Reactor fuel that has been stored in the $K$ Basins ( $K$ Basin fuel). The equations herein are submitted for reference in the Project Technical Databook (Duncan 1997) to be used for both process and safety base calculations. Reaction rate constants are necessary input parameters for calculation of the reaction of $\mathrm{K}$ Basin fuel metal in Multi-Canister Overpacks (MCOs) with a number of different atmospheres. The reaction rate constants in this Project Technical Databook submittal are the best estimates based on the available data. The equations will be updated when sufficient additional data or an expanded understanding of materials behavior are available to warrant a revision.

\subsection{SUMMARY STATEMENT OF PARAMETER}

The reaction rate constant is defined in the following general equation.

$$
R=A_{s} \times F_{a} \times k
$$

where:

$\mathrm{R}=$ Reaction rate

$A_{s}=$ Geometric fuel surface area

$F_{a}=$ Enhancement factor to account for the following: (1) true reacting surface sometimes called a roughness factor, (2) alloy inclusions including hydrides, and (3) characteristics of the native oxide present on the reacting surface

$k=$ Temperature dependent reaction rate, typically an Arrhenius form.

For Process Calculations

$\log k=4.451-2177 / T$ for $T \leq 568 K$

$\log k=7.188-3732 / T$ for $568<T \leq 695 K$

and

$$
\log k=3.857-1416 / T \text { for } T>695 K
$$


where:

$k$ is weight gain in $\mathrm{mg} / \mathrm{cm}^{2} / \mathrm{hr}$ and $T$ is temperature in degrees Kelvin (K).

Dry air is defined by less than 15 vppm $\mathrm{H}_{2} \mathrm{O}$.

Upper Bound for Safety Basis

$\log k=5.499-2177 / T$ for $T \leq 655 K$

and

$\log k=4.338-1416 / T$ for $T>655 K$

Lower Bound for Safety Basis

$\log k=8.946-4638 / T$ for $T \leqq 352 K$

$\log k=6.370-3732 / T$ for $352<T \leq 773 k$

and

$\log k=3.377-1416 / T$ for $T>773 K$

Enhancement Factor $F_{a}$

The enhancement factor $F_{a}$ for dry air oxidation is defined to be

$$
F_{a}=1
$$

\section{Sample Calculation of Reaction Rate}

For process calculations in a MCO a temperature of $75{ }^{\circ} \mathrm{C}$ was selected for the reaction rate for $K$ Basin fuel oxidation in dry air.

The geometric surface area of an MCO for process calculations is defined to be (Duncan 1997)

$$
A_{s}=3 \times 10^{3} \mathrm{~cm}^{2}
$$

for these calculations.

Therefore:

$$
\begin{aligned}
\mathrm{R} & =A_{\mathrm{s}} \times \mathrm{F}_{\mathrm{a}} \times \mathrm{k} \\
& =\left(3 \times 10^{3} \mathrm{~cm}^{2}\right) \times(1) \times\left(10^{4.451-2177 / 348}\right) \\
& =\left(3 \times 10^{3} \mathrm{~cm}^{2}\right) \times(1) \times\left(0.0157 \mathrm{mg} / \mathrm{cm}^{2} / \mathrm{hr}\right) \\
& =47.0 \mathrm{mg} \text { of weight gain/hour. }
\end{aligned}
$$


Oxidation of Clean Surfaces

A two-step linear model for the oxidation of relatively clean uranium surfaces in dry air is provided in Appendix D.

\subsection{ASSUMPTIONS}

The rate constants, $k$, recommended are for linear oxidation according to the following equation:

$$
W=k \times t
$$

where:

$W$ is weight gain and $t$ is time.

The initial oxidation of clean, unoxidized uranium surfaces in dry air occurs in a non-linear manner which has been modeled by Pearce and Kay (1987), Colmenares (1984) and Ritchie (1984) using a parabolic equation:

$$
W=k \times t^{1 / 2}
$$

With time an oxide layer develops on the surface and the rate decreases, progressing toward a linear rate. A paralinear equation has been used by Pearce and Kay (1987) and Colmenares (1984) to describe long-term oxidation in dry air. This equation has the form

$$
W=k_{p} \times t^{1 / 2}+k_{l} \times t
$$

where:

$k_{p}$ and $k_{l}$ are the parabolic and linear rate constants, respectively.

It is assumed that exposure of the fuel to the $K$ Basin water has resulted in significant oxidation of the uranium surfaces and that only linear oxidation will be observed in dry air. This assumes that the non-linear component of the oxidation of clean surfaces will be insignificant due to the oxide buildup from long-time water exposure. Oxidation will therefore be linear and progress according to Equation (3.1).

\subsection{SOURCES OF INFORMATION}

Literature data for 1 inear oxidation of unirradiated uranium in dry air were extracted from Figures 5 and 6 of Pearce (1989). These data, 1 isted in Appendix $A$, were used in this document to derive a rate law for unirradiated uranium. 
Supplemental data for dry air oxidation of uranium fuel was obtained from the French in an unpublished work by Paidassi et a1. (1979) and from Bennett et a]. (1975). These data, 1isted in Appendix B, include results from testing unirradiated and irradiated fue 1 materials.

Dry air oxidation data for damaged/corroded K Basin fuel was obtained from Abrefah et al. (1998). Appendix C 1 ists the data used by Abrefah to derive a rate law for oxidation of $\mathrm{K}$ Basin SNF at temperature below $275^{\circ} \mathrm{C}$.

\subsection{REACTION RATES}

The issue is the number of corrosion events that occur in a given time at a given temperature. This is the product of the reactive fuel surface area and the corresponding rate constant. In actual practice it may not be necessary to know each of these two parameters if measurements of reaction products such as hydrogen are conducted. However, for modeling calculations specific values for each of these parameters are necessary. A fuel surface area recommendation was prepared and submitted by Lawrence (1998) for use in the Project Technical Databook (Duncan 1997). The reaction rate equations recommended here for inclusion in the Project Databook are consistent with the terms defined and used in the Databook.

\subsection{DEFINITION OF TERMS}

The primary interest in estimating oxidation rates of $K$ Basin fuel in an MCO originates with the need to define the rate of potential chemical reactions. These reactions are exothermic and can result in the net production of gaseous products. Therefore, the reaction rates become important factors for predicting thermal transients in an MCO and the potential for over pressurization.

The reaction of uranium metal fuel in an MCO with a number of different reactants will occur as an MCO is loaded at the basins, transferred, dried, staged, conditioned, and stored. The reactants of interest can vary with the type of analysis under consideration (e.g., prediction of routine processing, analysis of accident conditions, etc.), however, the main reactants of interest include water, oxygen, and hydrogen. The general form of the relationship used to predict reaction rates is as follows.

$$
R=A_{s} \times F_{a} \times k
$$


where:

$$
\begin{aligned}
R= & \text { Uranium reaction rate, } m g \text { of weight gain } / \mathrm{hr} \\
A_{s}= & \text { Geometric surface area of uranium exposed to reactants, } \mathrm{cm}^{2} \\
\mathrm{~F}_{\mathrm{a}}= & \text { Reactivity factor, to account for the true reacting surface } \\
& \text { sometimes called a roughness factor, dimensionless } \\
\mathrm{k}= & \text { Reaction rate constant, } \mathrm{mg} \text { of weight gain } / \mathrm{hr}-\mathrm{cm}^{2}
\end{aligned}
$$

These terms are defined in more detail as follows.

Reaction Rate $(R)$--The reaction rate describes the mass of oxygen reacted per unit of time.

Geometric Surface Area $\left(A_{s}\right)$--The area of uranium exposed to reactants. estimated by geometric dimensions assuming a smooth surface.

Reactivity Factor $\mathrm{F}_{\mathrm{a}}$--This enhancement factor accounts for the following: (1) the true reacting surface which can conceptually be thought of as the roughness of the actual uranium metal surface, increasing the smooth surface area associated with the geometric dimensions, (2) alloy inclusions including hydride, and (3) characteristics of the native oxide present on the reacting surface.

Temperature Dependent Rate Constant $(k)--$ The reaction rate constant is typically an exponential function of inverse absolute temperature (Arrhenius relationship).

Reaction rate data are typically generated in the laboratory under controlled conditions and, for solid/gas or solid/liquid reactions, reported as a function of reactant concentration, temperature, and surface area. Placing the reaction rate data on a unit surface area basis allows use of the laboratory data for a variety of different configurations that may be encountered in practice. Specimens used to obtain laboratory data have some undefined degree of surface roughness which is ignored in this recommendation for dry air rate constant. Laboratory observations typically focus on determining the reaction rate dependence on temperature and reactant concentration.

\subsection{AIR OXIDATION OF URANIUM} is:

The chemical reaction for which the reaction rate constant will be used

$$
\mathrm{U}+\left(\frac{2+\mathrm{X}}{2}\right) \mathrm{O}_{2} \rightarrow \mathrm{UO}_{2+\mathrm{X}}
$$


Values for $x$ range from $x \leq 0.25$ (Colmenares 1984) to $0.2<x<0.4$ (Orman 1976; Ritchie 1981) for temperatures up to $200^{\circ} \mathrm{C}$ in dry air. At temperatures greater than $275{ }^{\circ} \mathrm{C} \mathrm{U}_{3} \mathrm{O}_{8}$ starts to form (Orman et al. 1969).

Dry air is defined by less than $15 \mathrm{vppm} \mathrm{H}_{2} \mathrm{O}$.

\subsection{LITERATURE DATA BASE FOR ANALYSIS}

The reaction rate data base for dry air oxidation is a collection of linear rate data for unirradiated uranium from a large number of authors. The data base is shown in Figure 1 and tabulated in Appendix A. The Pearce equations previously selected by Cooper (1997) for the Technical Databook submittal was a correlation of linear rate data from the work of Pearce and Kay (1987) and recommended in Pearce (1989). These equations were compared to the literature data in Pearce (1989) and were not a correlation of these data.

\subsection{REGRESSION ANALYSIS OF LITERATURE DATA}

The literature data base (Appendix A) for unirradiated uranium expressed as the natural logarithm versus one over the absolute temperatures, $\mathrm{i} . \mathrm{e.}, 1 / \mathrm{T}$, was fit to 7 inear equations over two and three different temperature intervals. An examination of the fits to the data lead to the selection of two temperature ranges where the regression analysis fixed the temperature where the two curves intersected. The data was also fit to a second order equation, i.e., $\log k=a+b T^{2}+c / T$ with good statistics, i.e., $R^{2}=0.95$ however, this equation form was not selected since reaction rate data is normally expressed as a linear equation. The resulting equations are:

$\log k=7.188-3732 / T$ for temperatures $\leq 695 \mathrm{~K}\left(422{ }^{\circ} \mathrm{C}\right)$

and

$\log k=3.857-1416 / T$ for temperatures $>695 K$

where:

$k$ is the weight gain in $\mathrm{mg} / \mathrm{cm}^{2} / \mathrm{hr}$ and $\mathrm{T}$ is temperature in $\mathrm{K}$.

Dry air is defined by less than 15 vppm $\mathrm{H}_{2} \mathrm{O}$.

The corresponding upper bound $95 \%$ prediction interval lines for the data are approximated by:

$\log k=8.011-3732 / T$ for temperature $\leq 631 \mathrm{~K}\left(358^{\circ} \mathrm{C}\right)$

and

$\log k=4.338^{\circ}-1416 / T$ for temperature $>631 \mathrm{~K}$. 


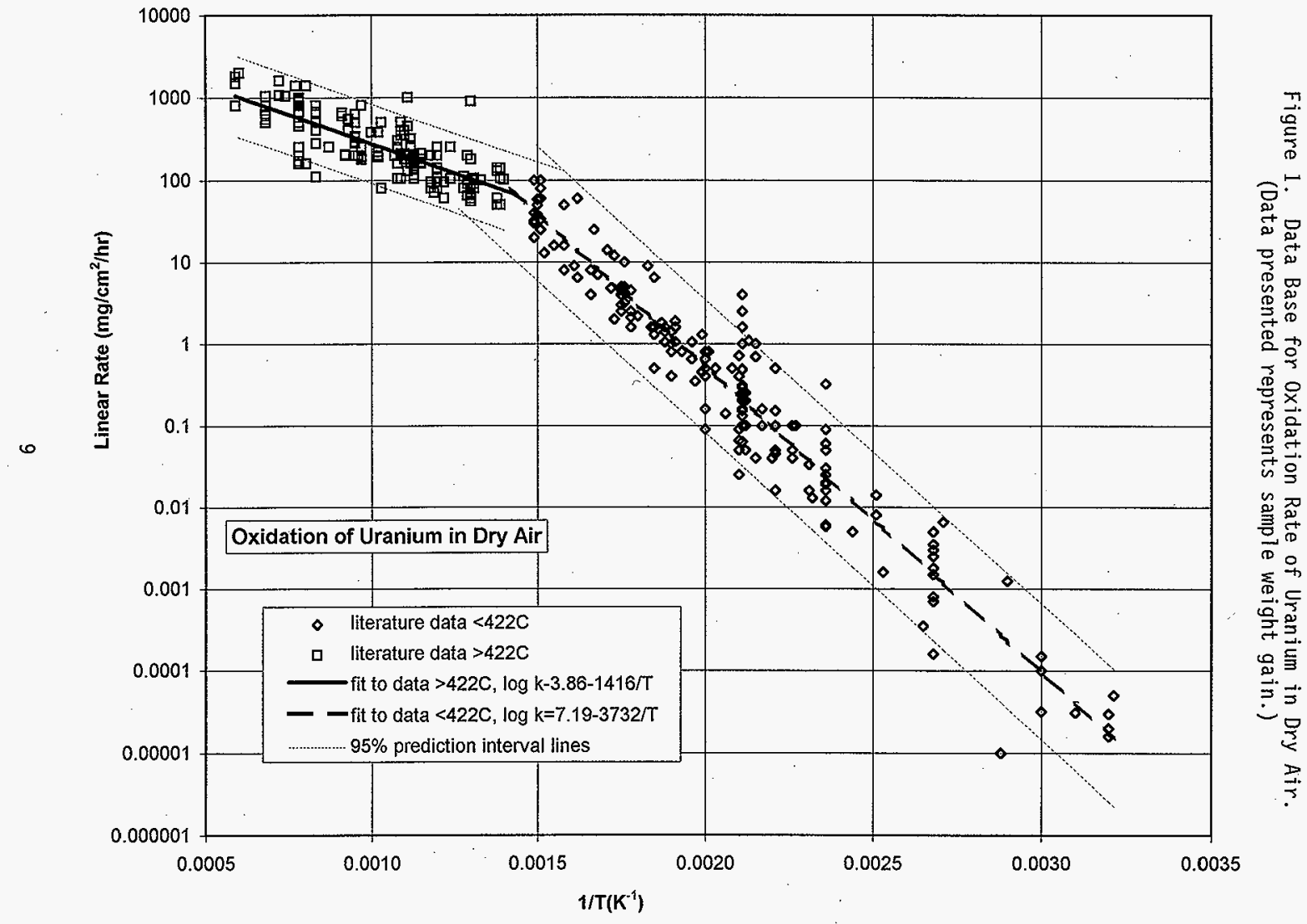


HNF-SD-SNF-CN-019, Rev. 0

The corresponding lower bound $95 \%$ prediction interval 1 ines for the data are approximated by:

$\log k=6.370-3732 / \mathrm{T}$ for temperatures $\leq 773 \mathrm{~K}\left(500{ }^{\circ} \mathrm{C}\right)$

and

$\log k=3.377-1416 / T$ for temperatures $>773 \mathrm{~K}$

The upper and lower 95\% prediction interval 1 ines from the regression analysis fixed the temperatures where the lines intersect resulting in different temperature limits for the upper and lower bound equations.

The two nominal equations and the upper and lower prediction equations for the data are compared to the data base in Figure 1. The upper and lower bounds adequately bracket the data and do not unduly compensate for the data scatter at any temperature or at the upper and lower ranges of the data. The goodness of the data fit is $R^{2}=0.93$ for the lower temperature range and $R^{2}=0.61$ for the higher temperature ranges.

The regression equation determined from the data can be used to predict a value for $k$ at a given temperature, T. To insure that this prediction reflects the variability of the data used, a prediction interval was

calculated at a given level of confidence. The $95 \%$ level was selected for the prediction interval, that is, $95 \%$ of the variability of the data for values of $k$ predicted by the appropriate equation fall within the prediction interval.

The Pearce equations for dry air oxidation are as follows (Pearce 1989):

$\log k=8.9464-4638.2 / T$ for $T<597 K$

$\log k=28.381-7 \log (T)-4638.2 / T$ for $T>597 K$

These equations, presented in Revision 1 of the Techical Databook, are compared to the literature data base for unirradiated uranium in Figure 2.

\subsection{COMPARISON TO FRENCH AND ENGLISH URANIUM DATA}

Experimental work has been carried out in France and England in the 1ate $60^{\prime}$ 's and 70's (Paidassi et al. 1979; Bennett et al. 1975) in order to assess the behavior of uranium in dry and wet air. The uranjum alloys used for this experimental work were Sicral FI for the French and the so-called adjusted uranium for the English measurements.

\subsubsection{Comparison to Unirradiated Uranium Data}

Available French data for unirradiated uranium were compared to the 7iterature data and the regression analys is in Figure $3(\mathrm{a})$. This evaluation shows these data to be within the data scatter and will be adequately represented by the equations selected. The French data are listed in Appendix B. 
HNF-SD-SNF-CN-019, Rev. 0

Figure 2. Comparison of the Pearce Equations and the Regression Analysis of the Literature Data for Oxidation of Uranium in Dry Air.

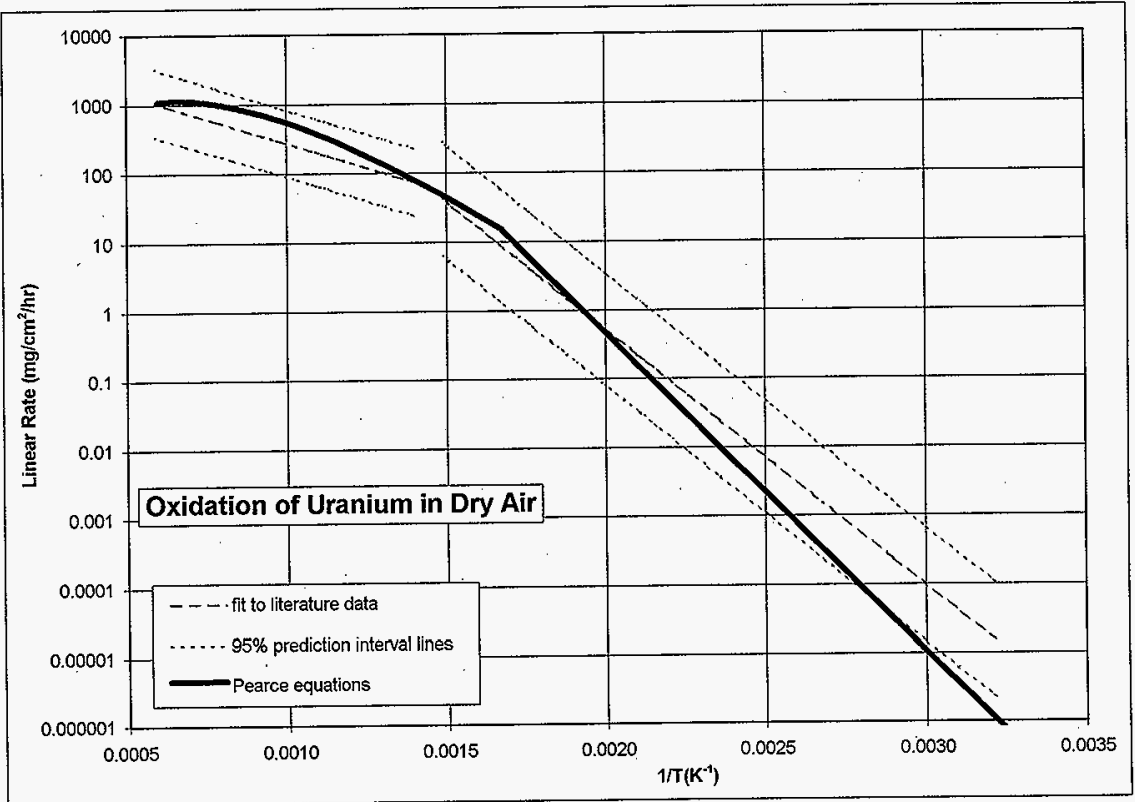


Figure 3. Comparison of Regression Analysis for Dry Air Oxidation of Uranium with French and English Data for

(a) Unirradiated Uranium and (b) Irradiated Uranium.
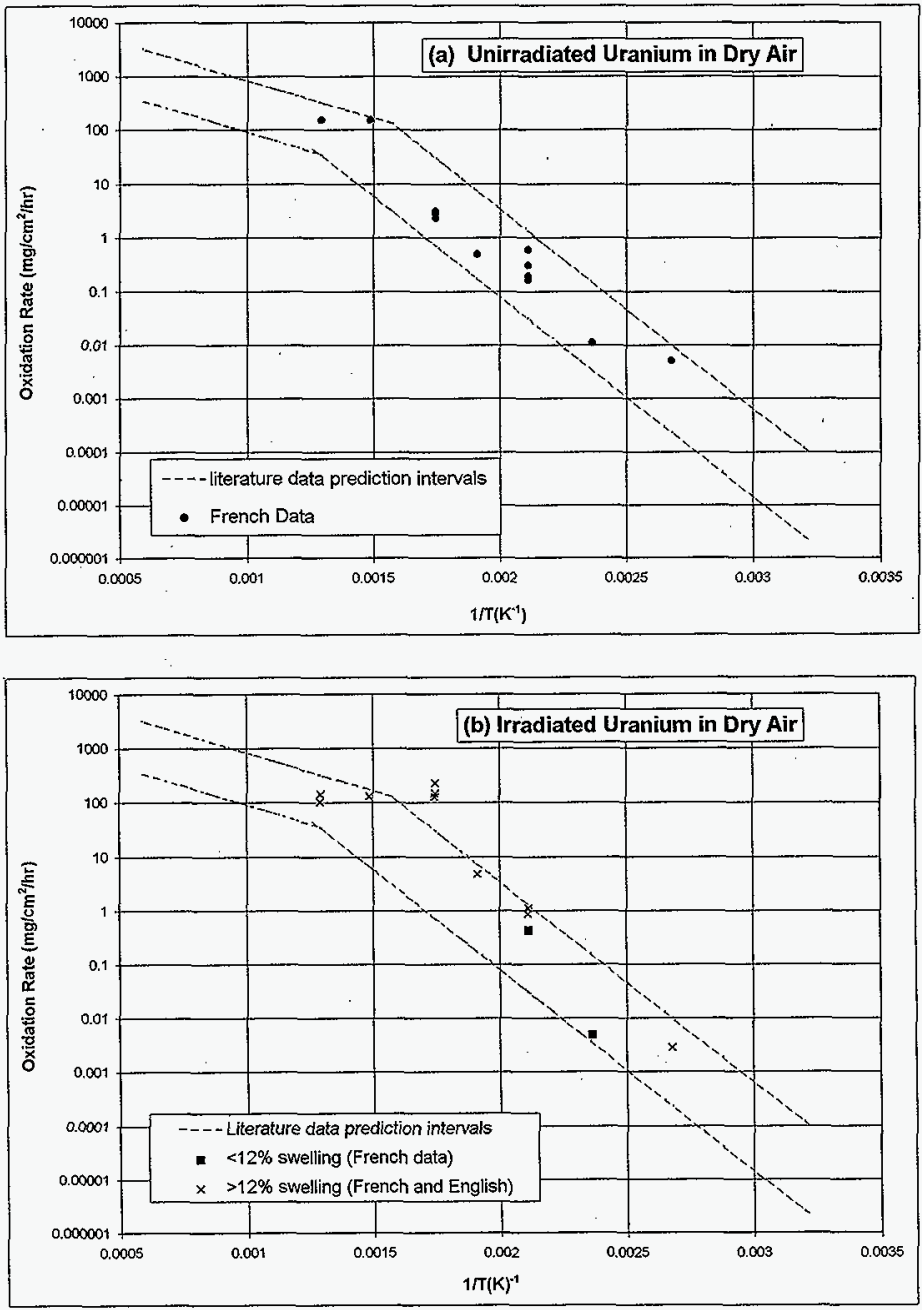


\subsubsection{Comparison to Irradiated Uranium Data}

Limited French and English data available for irradiated uranium was compared to the 1 iterature data regression analys is in Figure $3(\mathrm{~b})$. The irradiated data were divided into two groups, corresponding to the fuel with less than $12 \%$ irradiation induced swelling and fuel with more than $12 \%$ swelling (Appendix B).

Comparing the unirradiated literature data and the irradiated (low swelling) data shows no significant influence of Tow swelling irradiation on the oxidation of uranium [Figure $3(\mathrm{~b})]$.

On the other hand, some of the high swelling fuels data are outside the regression analysis for the literature data which is consistent with current understanding of the influence of swelling on oxidation rates. Voids and porosity are created in the fuels with high exposure resulting in higher fuel swelling. This additional porosity increases greatly the effective fuel surface area available for oxidation and correspondingly a higher measured. oxidation rate.

The $\mathrm{N}$ Reactor fuel stored in the $\mathrm{K}$ Basins represents relatively row exposure fuel with low fuel swelling. Fuel burnup in the $K$ Basins is mostly in the $11 \%$ to $15 \%{ }^{240} \mathrm{Pu}$ range (Praga and Wi1l is 1998) which translates to average fue]-column exposures of 2200 to 3900 megawatt days per metric ton uranium (MWD/MTU). Due to the typical $\mathrm{N}$ Reactor fuel column characteristics individual fuel element exposure can be $50 \%$ greater than the fuel-column average. This results in maximum fuel element exposures of $6000 \mathrm{MWD} / \mathrm{MTU}$. Maximum fuel swelling of 3.5 vol\% was measured in $\mathrm{N}$-Fuel irradiated to 3100 MWD/MTU (Goffard and Last 1964). Using the model proposed by Goffard and Last, N-Fuel exposed to $6000 \mathrm{MWD} / \mathrm{MTU}$ wi1l swe 11 about 7.5 vol\%. Therefore, the expected swelling of $K$ Basin fuel due to reactor exposure is below the threshold for increasing the oxidation rate.

\subsection{COMPARISON TO $K$ BASIN FUEL DATA}

Oxidation rates in dry air were measured for selected samples from the damaged portions of $N$ Reactor fuel elements that were stored in the $K$ West Basin (Abrefah et a1. 1998). The laboratory measurements of $K$ Basin spent nuclear fuel (SNF) are based on sample weight gain measured on the ThermoGravimetric Analysis (TGA) System and exposed geometric surface area measured from the samples' cut surfaces. These surfaces were visually free of cracks and surface voids. The measured rate data is an average of approximate linear portions of the samples weight gain versus time data plots for given sample temperatures. Two separate and independent analyses were performed using the TGA measurement data (Abrefah et a1. 1998; Trimble and Welsh 1998).

\subsubsection{K Basin Fuel Data Analys is}

Seventeen samples from damaged/corroded portions of $K$ Basin fuel elements were tested in dry air at temperatures ranging from $69{ }^{\circ} \mathrm{C}$ to $400{ }^{\circ} \mathrm{C}$. Seven of these tests, at temperatures from $69{ }^{\circ} \mathrm{C}$ to $275^{\circ} \mathrm{C}$, exhibited normal oxidation behavior producing typical weight-gain curves (Abrefah et al. 1998). The 
results from eight tests were atypical, and two additional tests used anomalous samples. Abrefah derived linear reaction rate constants for each of the seven normal test curves using regressions of the linear portion of each data curve that followed the initial parabolic portion of the test. This procedure is the normally accepted method for determining linear rate constants from reaction data and was used in deriving the linear rates reported in the literature (Table AI). The $K$ Basin SNF data used by Abrefah are summarized in Appendix $C$ and plotted on Figure $4(a)$.

The SNF data were fitted to an equation of the same form as used for the literature data. The nominal regression 1 ine, the $95 \%$ confidence interval on the mean, and the bounds on the $95 \%$ prediction interval are shown on Figure $4(\mathrm{a})$. The $95 \%$ confidence interval on the mean is the bounds on the certainty of the true mean of all SNF data, where the data set plotted on Figure $4(a)$ represents a sample of all SNF data. (There is a $5 \%$ probability that the mean reaction rate at a given temperature falls outside the $95 \%$ confidence interval). The $95 \%$ prediction interval is the predicted bounds for $95 \%$ of a 17 data in the complete data set, where the complete data set represents a11 SNF surfaces in the $K$ Basins. The nominal equation is

$\log k=4.451-2177 / \mathrm{T}$.

The $95 \%$ prediction interval 1 ines are approximated by the following equations:

Upper bound

$\log k=5.499-2177 / T$

Lower bound

$\log k=3.402-2177 / \mathrm{T}$.

The $K$ Basin SNF test data were also analyzed by Trimble and Welsh (1998). This analysis looked at the data from sixteen of the seventeen tests. The test run not evaluated (Run 21 at $300^{\circ} \mathrm{C}$ ) used an anomalous fuel material sample (Abrefah et al. 1998). All positive slopes in the data were used to derive a time-average rate constant for each test. The resulting sixteen data at $69{ }^{\circ} \mathrm{C}$ to $400{ }^{\circ} \mathrm{C}$ were evaluated on an Arrhenius plot. Statistical analysis found two of the rate constants to be probable outlier data relative to the remaining fourteen data. Regression of the fourteen data produced the following rate $\mathrm{l}$ aw equation:

$\log k=3.459-1802 / \mathrm{T}$.

These data, the regression 1 ine, the $95 \%$ prediction interval 1 ines and the lines for the $95 \%$ confidence interval on the mean are plotted on Figure $4(\mathrm{~b})$.

The confidence interval on the mean from the two SNF data sets, (Abrefah et al. 1998; Trimble and Welsh 1998), are compared on Figure 4 (c). The confidence intervals overlap substantially indicating that no significant difference exists between the two equations. Since the Abrefah data represents the normally accepted method for determining linear rate constant, the Abrefah rate law for $K$ Basin SNF was used in the following discussions to derive rate law equations recommended by this document. 
Figure 4. K Basin Fue I Dry Air 0xidation Data and Analysis. (a) Analysis by Abrefah et al., (1998) (b) Analysis by Trimble and Welsh (1998) (c) Comparison of Analysis Results.
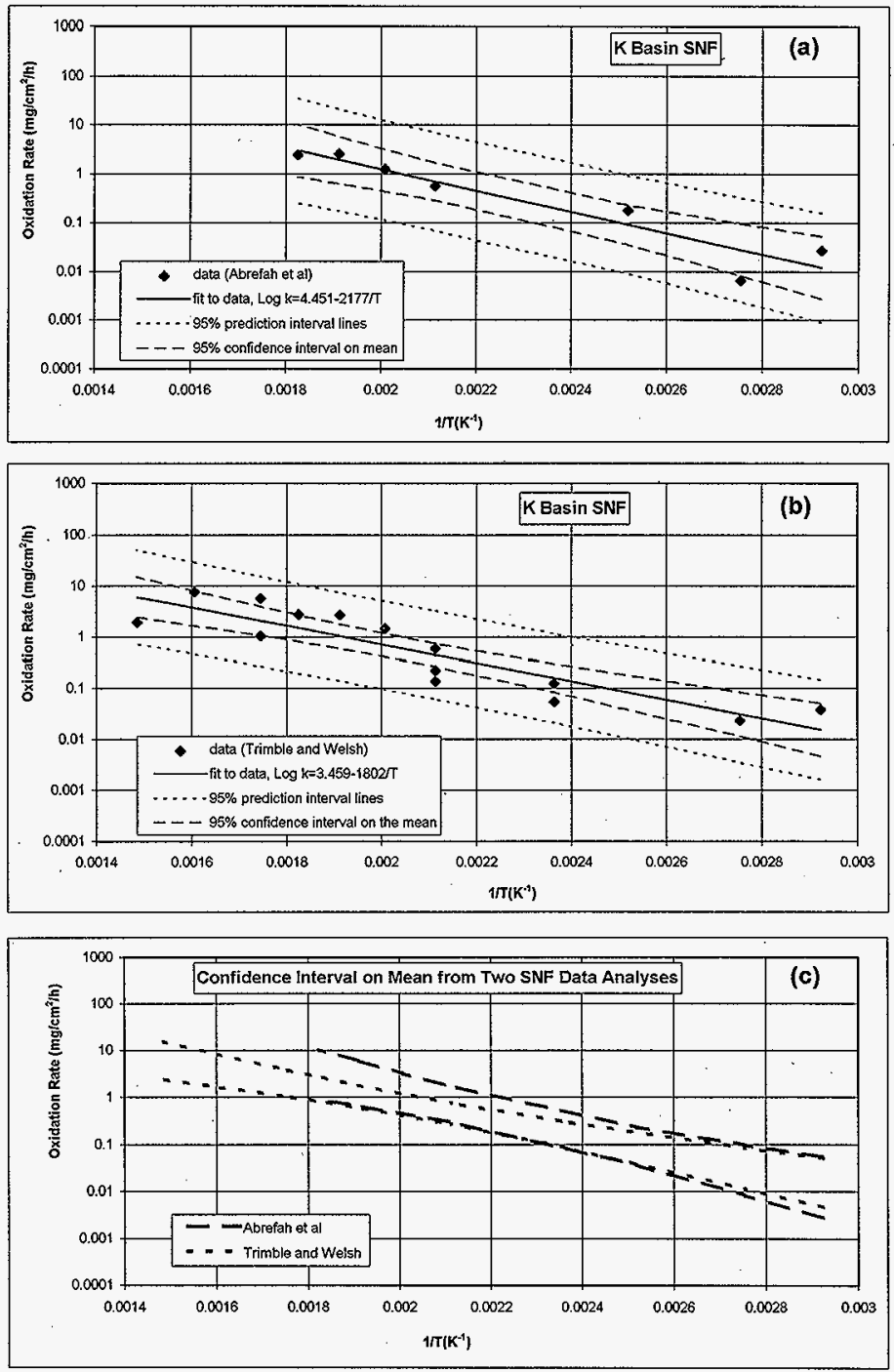
The SNF data are compared on Figure 5 to the regression 7 ines and the $95 \%$ prediction intervals to the data for unirradiated uranium (1iterature) data. The slopes of the two rate law equations were statistically analyzed for equality and were determined to not be equal. The SNF equation has less temperature dependence than does the literature data equation with the 1ines crossing at $295^{\circ} \mathrm{C}$. At and above $200{ }^{\circ} \mathrm{C}$ the SNF data falls within the bounds of the literature data but are above those bounds below about $150{ }^{\circ} \mathrm{C}$.

\subsubsection{Uncertainty in Spent Nuclear Fuel Data}

The SNF samples tested for oxidation rate data were derived from two fue] elements from the closed canisters in $\mathrm{K}$ West Basin. The elements were damaged and corroded and the samples were from locations near the damage. These elements were intended to represent damaged fuel in the $K$ West Basin. There are approximately 105,000 fuel assemblies (210,000 inner and outer elements) stored in the K East and K West Basins (Praga and Wi11is 1998). An estimated 70,000 of these elements are damaged exposing an estimated $1,000,000 \mathrm{~cm}^{2}$ of uranium surface (Lawrence 1998). If corroded material causes accelerated corrosion, then measured oxidation rates from the tested samples would be expected to be representative of the oxidation rates for the total population of exposed fuel surfaces. However, because of the very large population of fuel in the Basins which have been irradiated and stored over a 10 to 30 year time frame, and because of the large variability in damaged and corrosion of these elements, there could be a significantly large variably in the material and its properties. Considering this and the very small sample size (two elements tested out of 70,000 damaged), the element-to-element variability has not been evaluated. Thus, there could be considerably more variability than observed by these SNF tests with some of that untested variability on the positive side of the oxidation rates. Caution should therefore be exercised in using these data.

\subsection{RECOMMENDED REACTION RATE EQUATIONS}

The recommended dry air reaction rate equations for the surfaces of $K$ Basin SNF is based on the equations for damaged/corroded SNF at low temperature ( $T \leq 568 \mathrm{~K}$ ) and on the literature data equations for unirradiated uranium at higher temperature. The temperatures at which the various nominat regression lines meet and at which the upper bounds meet and the lower bounds meet, define the break points for the recommended nominal, upper bound, and lower bound equations. The upper and lower bound equations are approximations to the $95 \%$ prediction interval lines. The bounds selected were the extremes available from the varjous prediction equations, except that the nominal Pearce Equation (5.1) was used where it fell below the lower bound for the Titerature data at $\mathrm{T}=352 \mathrm{~K}$.

For Process Calculations

$$
\begin{aligned}
& \log k=4.451-2177 / T \text { for } T \leq 568 K \\
& \log k=7.188-3732 / T \text { for } 568<T \leq 695 K \\
& \log k=3.857-1416 / T \text { for } T>695 K
\end{aligned}
$$


Figure 5. Comparison of Data Base and Regression Analys is for Dry Air 0xidation of Uranium with K Basin Fuel Data. (Data presented represents sample weight gain.)

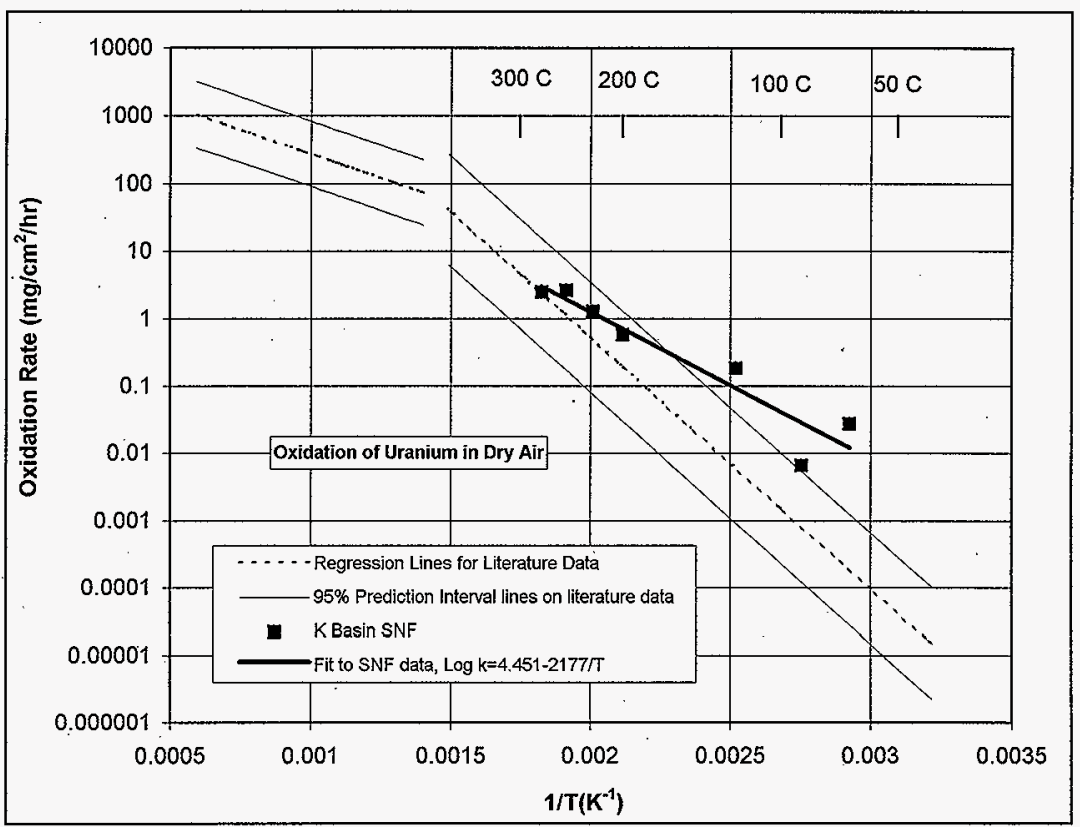


Upper Bound for Safety Basis

$$
\log k=5.499-2177 / T \text { for } T \leq 655 K
$$

and

$\log k=4.338-1416 / T$ for $T>655 K$

Lower Bound for Safety Basis

$\log k=8.946-4638 / T$ for $T \leq 352 K$

$\log k=6.370-3732 / T$ for $352<T \leq 773 \mathrm{~K}$

and

$\log k=3.377-1416 / T$ for $T>773 K$

Where: Kelvin.

$\mathrm{k}$ is rate of weight gain in $\mathrm{mg} / \mathrm{cm}^{2} / \mathrm{hr}$ and $\mathrm{T}$ is temperature in degrees

The recommended dry air reaction rate equations are represented graphically on Figure 6 .

\subsection{ENFANCEMENT FACTOR}

The rate constant temperature dependence observed for the $K$ Basin SNF is significantly different from that for unirradiated uranium literature data (Figure 5) or for the Pearce equation for dry air oxidation. This is also true for other dry air oxidation rate law equations found in the Titerature (Colmenares 1984; McGillivary 1994; Ritchie 1981). Because of this difference in rate law slope it is not practical to assign an enhancement factor to an existing equation to describe the oxidation of $K$ Basin SNF. Thus, the reaction rate enhancement is embodied in the recommended rate law equations for $\mathrm{K}$ Basin SNF and in the upper bounds to those equations, and the enhancement factor, $F_{a}$, is assigned a value of one.

\subsection{OXIDATION OF CLEAN SURFACES}

The reaction rate equations presented in Section 5.7 are for linear oxidation of $\mathrm{K}$ Basin fuel. As previously discussed (Section 3), relatively clean surfaces will initially oxidize at a parabolic or non-linear rate. Such oxidation was observed in the testing of SNF at temperatures below $200^{\circ} \mathrm{C}$. Since this time dependent rate of oxidation can be substantial, a two-step linear oxidation rate was developed and is presented in Appendix D. If needed the equations in Appendix $D$ can be used to evaluate the oxidation of relatively clean surfaces of $\mathrm{K}$ Basin SNF in dry air. Previously unexposed fuel surfaces created by fuel breakage during washing prior to MCO loading is an example of what could be relatively clean surfaces. 
Figure 6. Graphical Representation of the Recommended Reaction Rate Equations for $\mathrm{K}$ Basin Fuel in Dry Air.
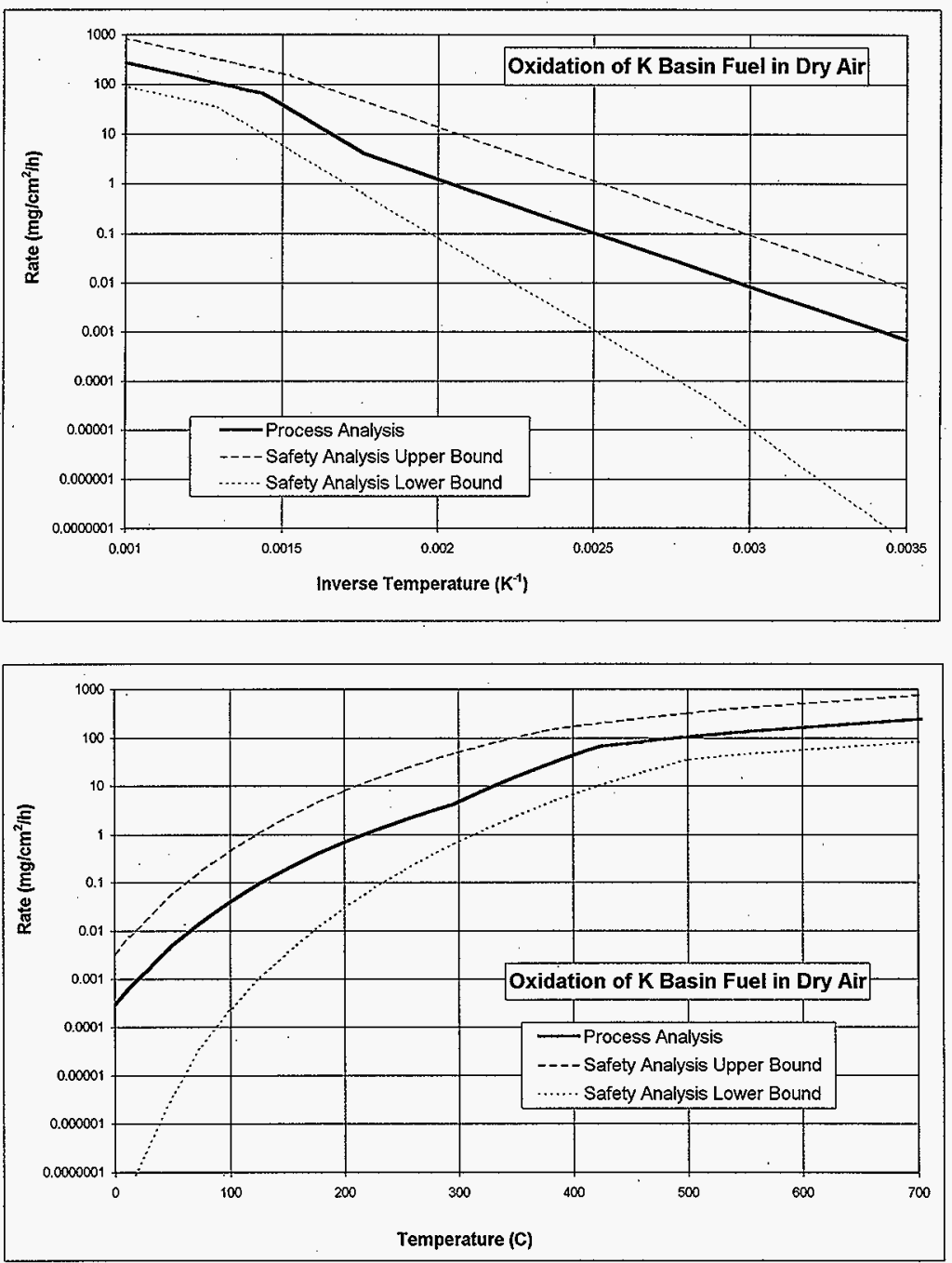


\subsection{REFERENCES}

Abrefah, J., H. C. Buchanan, W. M. Gerry, W. J. Gray, and S. C. Marschman, 1998, Dry Air Oxidation Kinetics of $K$ Basin Spent Nuclear Fuel,

PNNL-11786, Pacific Northwest National Laboratory, Richland, Washington.

Bennett, M. J., B. L. Myatt, D. R. U. Silvester, and J. E. Antil1, 1975, "The Oxidation Behavior of Uranium in Air at $50-300{ }^{\circ} \mathrm{C}, "$ Journal of Nuclear Materia7s, Vo1. 57, pp. 221-236.

Colmenares, C. A., 1984, "Oxidation of Mechanisms and Catalytic Properties of the Actinides," Progress in Solid State Chemistry, Vol. 15, pp. 257-364.

Cooper, T. D., 1997, SNF Project Recommended Reaction Rate Constants for Corrosion of $N$ Reactor Fue7, HNF-SD-SNF-TI-020, Rev. 1, B\&W Hanford Company, Richland, Washington.

Duncan, D. R., 1997, Spent Nuclear Fue7 Project Technical Databook, HNF-SD-SNF-TI-015, Rev. 2, Duke Engineering \& Services Hanford, Inc., Richland, Washington.

Goffard, J. W. and G. A. Last, 1964, Swelling Behavior of $N$ Reactor Fuel Elements, HW-79646, General Electric Hanford Atomic Products Operations, Richland, Washington.

Lawrence, L. A., 1998, Fuel Surface Area, HNF-SD-SNF-CN-017, Rev. 1, Duke Engineering \& Services Hanford, Inc., Richland, Washington.

MCGillivary, G. W., D. A. Geeson, and R. C. Greenwood, 1994, "Studies of the Kinetics and Mechanism of the Oxidation of Uranium by Dry and Moist Air," Journal of Nuclear Materials, Vol. 208, pp. 81-97, North Holland.

Orman, S., 1976 "Oxidation of Uranium and Uranium Alloys," Physical Meta77urgy of Uranium Alloys, Ed. J. J. Burke, Brook Hill Publishing Company.

Orman, S., G. Picton, and J. C. Ruckman, 1969, Journa7 of Oxidation of Meta7s, Vol. 1, (1969) p. 199.

Paidassi, J. R. Dominget, and J. Dixmier, 1979, Comportement en presence d'air ou d'eau de l'uranium et de combustibles metalligues a base d'uranium irradie ou non, CEA-SECMLG-11079, Unpubl ished Work, Atomic Energy Commission, Paris, France.

Pearce, R. J., 1989, A Review of the Rates of Reaction of Unirradiated Uranium in Gaseous Atmospheres, RD/B/6231/R86, Central Electric Generating Board, Berkeley Nuclear Laboratories, United Kingdom.

Pearce, R. J., and P. Kay, 1987, The Reaction of Uranium in the $\mathrm{U}_{-} \mathrm{O}_{2}-\mathrm{H}_{2} \mathrm{O}$ and $\mathrm{U}-\mathrm{H}_{2} \mathrm{O}$ Systems, TPRD/B/0954/R87, Central Electric Generating Board, Berkeley Nuclear Laboratories, United Kingdom. 


\subsection{REFERENCES (Continued)}

Praga, A. N., and W. L. Willis, 1998, 105-K Basin Material Design Basis Feed Description for Spent Nuclear Fue7 Project Facilities, HNF-SD-SNF-TI-009, Rev. 1, Duke Engineering \& Services Hanford, Inc., Richland, Washington.

Ritchie, A. G., 1984, "The Kinetics of the Initial Stages of the Reaction of Uranium with Oxygen," Journal of the Less-Common Metals, Vol. 98, pp. 193-214.

Ritchie, A. G., 1981, "A Review of the Rates of Reaction of Uranjum with Oxygen and Water Vapor at Temperatures Up to $300^{\circ} \mathrm{C},{ }^{\prime \prime}$ Journal of Nuclear Material, Vol. 102, pp. 170-182.

Trimble, D. J., and T. L. Welsh, 1998, Statistical Ana7ysis of Oxidation Rates for $K$ Basin Fuel in Dry Air, HNF-SD-SNF-CN-035, Rev. 1, Duke Engineering \& Services Hanford, Inc., Richland, Washington.

Waber, J. T., 1952, A Review of the Corrosion of Uranium and Its Alloys, LA-1524, Los Alamos National Laboratory, Los Alamos, New Mexico. 
HNF-SD-SNF-CN-019, Rev. 0

This page intentionally left blank. 
HNF-SD-SNF-CN-019, Rev. 0

\section{APPENDIX A \\ DATA BASE FOR DRY AIR OXIDATION OF UNIRRADIATED URANIUM}

The data for dry air oxidation of unirradiated uranium is listed in Tables A1 and A2 (Pearce 1989). The tables consider the temperature ranges for the regression anaiysis. Table Al includes the data and results of the regression analysis for temperatures below $694 \mathrm{~K}$ whereas Table A2 includes the data and results for temperatures greater than $694 \mathrm{~K}$. The tables also include the results of the regression analysis for the upper and lower $95 \%$ prediction intervals.

\section{References}

Pearce, R. J., 1989, A Review of the Rates of Reaction of Unirradiated Uranium in Gaseous Atmosphere Report, RD/B/6231/R86, Central Electric Generating Board, Berkeley Nuclear Laboratories, United Kingdom.

Waber, J. T., 1952, A Review of the Corrosion of Uranium and Its Alloys, LA-1524, Los Alamos National Laboratory, Los Alamos, New Mexico. 
Table A1. Data for Dry Air 0xidation of Unirradiated Uranium for Temperatures $\leq 441{ }^{\circ} \mathrm{C}$. (Continued)

\begin{tabular}{|c|c|c|c|c|c|c|c|}
\hline $\begin{array}{c}\text { Data } \\
\text { Point } \\
\end{array}$ & $\begin{array}{c}\text { Temperature } \\
\left({ }^{\circ} \mathrm{C}\right) \\
\end{array}$ & $10^{3} / \mathrm{T}\left(\mathrm{K}^{-1}\right)$ & $\begin{array}{c}\text { Oxidation } \\
\text { Rate }^{*} \\
\left(\mathrm{mg} / \mathrm{cm}^{2} / \mathrm{hr}\right) \\
\end{array}$ & $\begin{array}{l}\text { Data } \\
\text { Point } \\
\end{array}$ & $\begin{array}{l}\text { Temperature } \\
\left({ }^{\circ} \mathrm{C}\right)\end{array}$ & $10^{3} / \mathrm{T}\left(\mathrm{K}^{-1}\right)$ & $\begin{array}{c}\text { Oxidation } \\
\text { Rate* } \\
\left(\mathrm{mg} / \mathrm{cm}^{2} / \mathrm{hr}\right) \\
\end{array}$ \\
\hline 1 & 441 & 1.40 & $1.020 \mathrm{e}+02$ & 26 & 320 & 1.68 & $7.000 \mathrm{e}+00$ \\
\hline 2 & 398 & 1.49 & $2.000 \mathrm{e}+01$ & 27 & 310 & 1.71 & $1.400 \mathrm{e}+01$ \\
\hline 3 & 398 & 1.49 & $3.000 \mathrm{e}+01$ & 28 & 308 & 1.72 & $4.800 \mathrm{e}+00$ \\
\hline 4 & 398 & 1.49 & $3.200 \mathrm{e}+01$ & 29 & 305 & 1.73 & $1.200 \mathrm{e}+01$ \\
\hline 5 & 398 & 1.49 & $4.000 \mathrm{e}+01$ & 30 & 305 & 1.73 & $2.000 \mathrm{e}+00$ \\
\hline 6 & 398 & 1.49 & $1.000 \mathrm{e}+02$ & 31 & 300 & 1.75 & $4.000 \mathrm{e}+00$ \\
\hline 7 & 394 & 1.50 & $5.000 e+01$ & 32 & 300 & 1.75 & $5.000 \mathrm{e}+00$ \\
\hline 8 & 394 & 1.50 & $5.800 \mathrm{e}+01$ & 33 & 300 & 1.75 & $2.500 \mathrm{e}+00$ \\
\hline 9 & 394 & 1.50 & $3.800 \mathrm{e}+01$ & 34 & 300 & 1.75 & $3.000 \mathrm{e}+00$ \\
\hline 10 & 389 & 1.51 & $2.500 \mathrm{e}+01$ & 35 & 300 & 1.75 & $4.500 \mathrm{e}+00$ \\
\hline 11 & 389 & 1.51 & $8.000 \mathrm{e}+01$ & 36 & 295 & 1.76 & $4.300 \mathrm{e}+00$ \\
\hline 12 & 389 & 1.51 & $3.300 \mathrm{e}+01$ & 37 & 295 & 1.76 & $1.000 \mathrm{e}+01$ \\
\hline 13 & 389 & 1.51 & $1.000 \mathrm{e}+02$ & 38 & 295 & 1.76 & $5.000 e+00$ \\
\hline 14 & 389 & 1.51 & $6.000 e+01$ & 39 & 295 & 1.76 & $3.200 \mathrm{e}+00$ \\
\hline 15 & 385 & 1.52 & $1.300 \mathrm{e}+01$ & 40 & 290 & 1.78 & $2.100 \mathrm{e}+00$ \\
\hline 16 & 372 & 1.55 & $1.600 \mathrm{e}+01$ & 41 & 290 & $1.78^{\circ}$ & $1.600 \mathrm{e}+00$ \\
\hline 17 & 360 & 1.58 & $5.000 e+01$ & 42 & 290 & 1.78 & $4.500 \mathrm{e}+00$ \\
\hline 18 & 360 & 1.58 & $8.000 e+01$ & 43 & 290 & 1.78 & $2.500 \mathrm{e}+00$ \\
\hline 19 & 360 & 1.58 & $1.600 \mathrm{e}+01$ & 44 & 283 & 1.80 & $2.200 \mathrm{e}+00$ \\
\hline 20 & 384 & 1.61 & $9.000 \mathrm{e}+00$ & 45 & 274 & 1.83 & $9.000 e+00$ \\
\hline 21 & 344 & 1.62 & $6.500 \mathrm{e}+00$ & 46 & 270 & 1.84 & $1.600 \mathrm{e}+00$ \\
\hline 22 & 344 & 1.62 & $6.000 \mathrm{e}+0 \mathrm{l}$ & 47 & 268 & 1.85 & $1.300 \mathrm{e}+00$ \\
\hline 23 & 330 & 1.66 & $4.000 \mathrm{e}+00$ & 48 & 268 & 1.85 & $6.500 \mathrm{e}+00$ \\
\hline 24 & 330 & 1.66 & $8.000 e+00$ & 49 & 268 & 1.85 & $1.600 \mathrm{e}+00$ \\
\hline 25 & 325 & 1.67 & $2.500 \mathrm{e}+01$ & 50 & 268 & 1.85 & $5.000 \mathrm{e}-01$ \\
\hline
\end{tabular}

*Notation $1.020 \mathrm{e}+02$ ㅁ $1.020 \times 10^{2}$. 
HNF-SD-SNF-CN-019, Rev. 0

Table Al. Data for Dry Air 0xidation of Unirradiated Uranium for Temperatures $\leq 441{ }^{\circ} \mathrm{C}$. (Continued)

\begin{tabular}{|c|c|c|c|c|c|c|c|}
\hline $\begin{array}{l}\text { Data } \\
\text { Point }\end{array}$ & $\begin{array}{c}\text { Temperature } \\
\left({ }^{\circ} \mathrm{C}\right)\end{array}$ & $10^{3} / T\left(K^{-1}\right)$ & $\begin{array}{c}\text { Oxidation } \\
\text { Rate } \\
\left(\mathrm{mg} / \mathrm{cm}^{*} / \mathrm{hr}\right)\end{array}$ & $\begin{array}{l}\text { Data } \\
\text { Point }\end{array}$ & $\begin{array}{c}\text { Temperature } \\
\left({ }^{\circ} \mathrm{C}\right)\end{array}$ & $10^{3} / \mathrm{T}\left(\mathrm{K}^{-1}\right)$ & $\begin{array}{c}\text { 0xidation } \\
\text { Rate }^{*} \\
\left(\mathrm{mg} / \mathrm{cm}^{2} / \mathrm{hr}\right)\end{array}$ \\
\hline 51 & 262 & 1.87 & $1.800 \mathrm{e}+00$ & 76 & 212 & 2.06 & $1.400 \mathrm{e}-01$ \\
\hline 52 & 260 & 1.88 & $1.050 \mathrm{e}+00$ & 77 & 208 & 2.08 & $5.000 e-01$ \\
\hline 53 & 260 & 1.88 & $1.400 \mathrm{e}+00$ & 78 & 203 & 2.10 & $7.100 \mathrm{e}-01$ \\
\hline 54 & 260 & 1.88 & $1.600 \mathrm{e}+00$ & 79 & 203 & 2.10 & $9.000 \mathrm{e}-02$ \\
\hline 55 & 254 & 1.90 & $8.000 e-01$ & 80 & 203 & 2.10 & $6.500 \mathrm{e}-02$ \\
\hline 56 & 254 & 1.90 & $1.000 \mathrm{e}+00$ & 81 & 203 & 2.10 & $5.000 \mathrm{e}-02$ \\
\hline 57 & 254 & 1.90 & $4.000 \mathrm{e}-01$ & 82 & 203 & 2.10 & $2.500 \mathrm{e}-02$ \\
\hline 58 & 254 & 1.90 & $1.400 \mathrm{e}+00$ & 83 & 203 & 2.10 & $4.000 \mathrm{e}-01$ \\
\hline 59 & 250 & 1.91 & $1.050 \mathrm{e}+00$ & 84 & 200 & 2.11 & $1.600 \mathrm{e}+00$ \\
\hline 60 & 250 & 1.91 & $1.600 \mathrm{e}+00$ & 85 & 200 & 2.11 & $6.300 \mathrm{e}-02$ \\
\hline 61 & 250 & 1.91 & $1.900 \mathrm{e}+00$ & 86 & 200 & 2.11 & $1.300 \mathrm{e}-01$ \\
\hline 62 & 245 & 1.93 & $8.000 e-01$ & 87 & 200 & 2.11 & $1.000 \mathrm{e}+00$ \\
\hline 63 & 237 & 1.96 & $6.500 \mathrm{e}-01$ & 88 & 200 & 2.11 & $1.000 \mathrm{e}-01$ \\
\hline 64 & 237 & 1.96 & $1.050 \mathrm{e}+00$ & 89 & 200 & 2.11 & $2.500 \mathrm{e}+00$ \\
\hline 65 & 235 & 1.97 & $3.500 \mathrm{e}-01$ & 90 & 200 & 2.11 & $3.100 \mathrm{e}-01$ \\
\hline 66 & 230 & 1.99 & $1.300 \mathrm{e}+00$ & 91 & 200 & 2.11 & $2.100 \mathrm{e}-01$ \\
\hline 67 & 230 & 1.99 & $4.500 \mathrm{e}-01$ & 92 & 200 & 2.11 & 2. $300 \mathrm{e}-01$ \\
\hline 68 & 227 & 2.00 & $6.500 \mathrm{e}-01$ & 93 & 200 & 2.11 & $2.900 \mathrm{e}-01$ \\
\hline 69 & 227 & 2.00 & $5.000 \mathrm{e}-01$ & 94 & 200 & 2.11 & $4.000 \mathrm{e}+00$ \\
\hline 70 & 227 & 2.00 & $8.000 \mathrm{e}-01$ & 95 & 200 & 2.11 & $1.600 \mathrm{e}-01$ \\
\hline 71 & 227 & 2.00 & $4.000 \mathrm{e}-01$ & 96 & 200 & 2.11 & $2.500 e-01$ \\
\hline 72 & 227 & 2.00 & $1.600 \mathrm{e}-01$ & 97 & 200 & 2.11 & $1.500 e-01$ \\
\hline 73 & 227 & 2.00 & $9.000 \mathrm{e}-02$ & 98 & 200 & 2.11 & $4.800 \mathrm{e}-01$ \\
\hline 74 & 225 & 2.01 & $8.000 \mathrm{e}-01$ & 99 & 200 & 2.11 & $2.000 \mathrm{e}-01$ \\
\hline 75 & 220 & 2.03 & $5.000 e-01$ & 100 & 200 & 2.11 & $4.900 \mathrm{e}-01$ \\
\hline
\end{tabular}

*Notation $1.020 \mathrm{e}+02 \equiv 1.020 \times 10^{2}$. 
HNF-SD-SNF-CN-019, Rev. 0

Table Al. Data for Dry Air 0xidation of Unirradiated Uranium for Temperatures $\leq 441{ }^{\circ} \mathrm{C}$. (Continued)

\begin{tabular}{|c|c|c|c|c|c|c|c|}
\hline $\begin{array}{l}\text { Data } \\
\text { Point }\end{array}$ & $\begin{array}{c}\text { Temperature } \\
\left({ }^{\circ} \mathrm{C}\right)\end{array}$ & $10^{3} / \mathrm{T}\left(\mathrm{K}^{-1}\right)$ & $\begin{array}{c}\text { Oxidation } \\
\text { Rate } \\
\left(\mathrm{mg} / \mathrm{cm}^{\star} / \mathrm{hr}\right)\end{array}$ & $\begin{array}{l}\text { Data } \\
\text { Point } \\
\end{array}$ & $\begin{array}{c}\text { Temperature } \\
\left({ }^{\circ} \mathrm{C}\right)\end{array}$ & $10^{3} / T\left(K^{-1}\right)$ & $\begin{array}{c}\text { Oxidation } \\
\text { Rate }^{*} \\
\left(\mathrm{mg} / \mathrm{cm}^{2} / \mathrm{hr}\right)\end{array}$ \\
\hline 101 & 199 & 2.12 & $5.000 \mathrm{e}-02$ & 126 & 150 & 2.36 & $6.000 \mathrm{e}-03$ \\
\hline 102 & 199 & 2.12 & $2.000 \mathrm{e}-01$ & 127 & 150 & 2.36 & $1.200 \mathrm{e}-02$ \\
\hline 103 & 199 & 2.12 & $1.000 \mathrm{e}-01$ & 128 & 150 & 2.36 & $1.600 \mathrm{e}-02$ \\
\hline 104 & 199 & 2.12 & $2.500 \mathrm{e}-01$ & 129 & 150 & 2.36 & $1.900 \mathrm{e}-02$ \\
\hline 105 & 197 & 2.13 & $1.100 \mathrm{e}+00$ & 130 & 150 & 2.36 & $3.200 \mathrm{e}-01$ \\
\hline 106 & 192 & 2.15 & $7.000 \mathrm{e}-01$ & 131 & 150 & 2.36 & $5.800 \mathrm{e}-03$ \\
\hline 107 & 192 & 2.15 & $1.000 \mathrm{e}+00$ & 132 & 150 & 2.36 & $2.500 \mathrm{e}-02$ \\
\hline 108 & 192 & 2.15 & $4.000 \mathrm{e}-02$ & 133 & 150 & 2.36 & $3.000 \mathrm{e}-02$ \\
\hline 109 & 188 & 2.17 & $1.600 \mathrm{e}-0.1$ & 134 & 150 & 2.36 & $5.000 \mathrm{e}-02$ \\
\hline 110 & 188 & 2.17 & $1.000 \mathrm{e}-01$ & 135 & 150 & 2.36 & $6.000 \mathrm{e}-02$ \\
\hline 111 & 182 & 2.20 & $4.000 \mathrm{e}-02$ & 136 & 150 & 2.36 & $9.000 \mathrm{e}-02$ \\
\hline 112 & 180 & 2.21 & $4.500 \mathrm{e}-02$ & 137 & 137 & 2.44 & $5.000 \mathrm{e}-03$ \\
\hline 113 & 180 & 2.21 & $1.600 \mathrm{e}-02$ & 138 & 125 & 2.51 & $1.400 \mathrm{e}-02$ \\
\hline 114 & 180 & 2.21 & $1.500 \mathrm{e}-01$ & 139 & 125 & 2.51 & $8.000 \mathrm{e}-03$ \\
\hline 115 & 180 & 2.21 & $5.000 e-01$ & 140 & 122 & 2.53 & $1.600 \mathrm{e}-03$ \\
\hline 116 & 180 & 2.21 & $1.000 \mathrm{e}-01$ & 141 & 104 & 2.65 & $3.500 \mathrm{e}-04$ \\
\hline 117 & 180 & 2.21 & $5.000 \mathrm{e}-02$ & 142 & 100 & 2.68 & $1.600 \mathrm{e}-04$ \\
\hline 118 & 170 & $2.26^{\circ}$ & $4.000 \mathrm{e}-02$ & 143 & 100 & 2.68 & $7.000 \mathrm{e}-04$ \\
\hline 119 & 170 & 2.26 & $1.000 \mathrm{e}-01$ & 144 & 100 & 2.68 & $8.000 \mathrm{e}-04$ \\
\hline 120 & .170 & 2.26 & $5.000 \mathrm{e}-02$ & 145 & 100 & 2.68 & $1.500 \mathrm{e}-03$ \\
\hline 121 & 167 & 2.27 & $1.000 \mathrm{e}-01$ & 146 & 100 & 2.68 & $5.000 \mathrm{e}-03$ \\
\hline 122 & 160 & 2.31 & $3.300 \mathrm{e}-02$ & 147 & 100 & 2.68 & $3.500 \mathrm{e}-03$ \\
\hline 123 & 160 & 2.31 & $1.600 \mathrm{e}-02$ & 148 & 100 & 2.68 & $3.000 \mathrm{e}-03$ \\
\hline 124 & 158 & 2.32 & $1.300 \mathrm{e}-02$ & 149 & 100 & 2.68 & $2.500 \mathrm{e}-03$ \\
\hline 125 & 150 & 2.36 & $2.000 \mathrm{e}-02$ & 150 & 100 & 2.68 & $1.800 \mathrm{e}-03$ \\
\hline
\end{tabular}

*Notation $1.020 \mathrm{e}+02 \equiv 1.020 \times 10^{2}$. 
HNF-SD-SNF-CN-019, Rev. 0

Table Al. Data for Dry Air Oxidation of Unirradiated Uranium for Temperatures $\leq 441{ }^{\circ} \mathrm{C}$. (Continued)

\begin{tabular}{||c|c|c|c|c|c|c|c||}
\hline $\begin{array}{c}\text { Data } \\
\text { Point }\end{array}$ & $\begin{array}{c}\text { Temperature } \\
\left({ }^{\circ} \mathrm{C}\right)\end{array}$ & $\begin{array}{c}\text { 0xidation } \\
\text { Rate* } \\
\left(0^{3} / \mathrm{T}\left(\mathrm{K}^{-1}\right)\right.\end{array}$ & $\begin{array}{c}\text { Data } \\
\left(\mathrm{cm}^{2} / \mathrm{hr}\right)\end{array}$ & $\begin{array}{c}\text { Temperature } \\
\text { Point } \\
\left({ }^{\circ} \mathrm{C}\right)\end{array}$ & $\begin{array}{c}\text { Oxidation } \\
\text { Rate* } \\
\left(0^{3} / \mathrm{T}\left(\mathrm{K}^{-1}\right)\right.\end{array}$ \\
\hline 151 & 96 & 2.71 & $6.600 \mathrm{e}-03$ & 157 & 50 & 3.10 & $3.100 \mathrm{e}-05$ \\
\hline 152 & 74 & 2.88 & $1.000 \mathrm{e}-05$ & 158 & 40 & 3.20 & $1.600 \mathrm{e}-05$ \\
\hline 153 & 72 & 2.90 & $1.250 \mathrm{e}-03$ & 159 & 40 & 3.20 & $3.000 \mathrm{e}-05$ \\
\hline 154 & 60 & 3.00 & $3.200 \mathrm{e}-05$ & 160 & 40 & 3.20 & $2.000 \mathrm{e}-05$ \\
\hline 155 & 60 & 3.00 & $1.000 \mathrm{e}-04$ & $161^{1}$ & 38 & 3.24 & $5.000 \mathrm{e}-05$ \\
\hline 156 & 60 & 3.00 & $1.500 \mathrm{e}-04$ & & & & \\
\hline
\end{tabular}

'This data point was changed from Pearce (1989) using correct value from the referenced source (Waber 1952).

*Notation $1.020 \mathrm{e}+02 \equiv 1.020 \times 10^{2}$. 
Table A2. Data for Dry Air Oxidation of Unirradiated Uranium for Temperature $>441{ }^{\circ} \mathrm{C}$. (Continued)

\begin{tabular}{|c|c|c|c|c|c|c|c|}
\hline $\begin{array}{l}\text { Data } \\
\text { Point } \\
\end{array}$ & $\begin{array}{c}\text { Temperature } \\
\left({ }^{\circ} \mathrm{C}\right)\end{array}$ & $10^{3} / \mathrm{T}\left(\mathrm{K}^{-1}\right)$ & $\begin{array}{c}\text { Oxidation } \\
\text { Rate* } \\
\left(\mathrm{mg} / \mathrm{cm}^{2} / \mathrm{hr}\right) \\
\end{array}$ & $\begin{array}{l}\text { Data } \\
\text { Point } \\
\end{array}$ & $\begin{array}{c}\text { Temperature } \\
\left({ }^{\circ} \mathrm{C}\right) \\
\end{array}$ & $10^{3} / \mathrm{T}\left(\mathrm{K}^{-1}\right)$ & $\begin{array}{c}\text { Oxidation } \\
\text { Rate* } \\
\left(\mathrm{mg} / \mathrm{cm}^{2} / \mathrm{hr}\right) \\
\end{array}$ \\
\hline 1 & 1420 & 0.59 & $1.500 \mathrm{e}+03$ & 26 & 977 & 0.80 & $1.400 \mathrm{e}+03$ \\
\hline 2 & 1420 & 0.59 & $8.000 e+02$ & 27 & 977 & 0.80 & $1.600 \mathrm{e}+02$ \\
\hline 3 & 1420 & 0.59 & $1.800 \mathrm{e}+03$ & 28 & 930 & 0.83 & $4.000 e+02$ \\
\hline 4 & 1394 & 0.60 & 2. $.000 \mathrm{e}+03$ & 29 & 930 & 0.83 & $6.700 \mathrm{e}+02$ \\
\hline 5 & 1200 & 0.68 & $6.000 \mathrm{e}+02$ & 30 & 930 & 0.83 & $1.100 \mathrm{e}+02$ \\
\hline 6 & 1200 & 0.68 & $5.500 \mathrm{e}+02$ & 31 & 930 & 0.83 & $5.000 \mathrm{e}+02$ \\
\hline 7 & 1200 & 0.68 & $5.000 \mathrm{e}+02$ & 32 & 930 & 0.83 & $2.800 e+02$ \\
\hline 8 & 1200 & 0.68 & $1.050 \mathrm{e}+03$ & 33 & 930 & 0.83 & $8.000 \mathrm{e}+02$ \\
\hline 9 & 1200 & 0.68 & $8.000 \mathrm{e}+02$ & 34 & 875 & 0.87 & $2.500 \mathrm{e}+02$ \\
\hline 10 & 1116 & 0.72 & $1.070 \mathrm{e}+03$ & 35 & 825 & 0.91 & $6.000 \mathrm{e}+02$ \\
\hline 11 & 1116 & 0.72 & $1.600 \mathrm{e}+03$ & 36 & 825 & 0.91 & $6.500 \mathrm{e}+02$ \\
\hline 12 & 1108 & 0.74 & $1.050 \mathrm{e}+03$ & 37 & 814 & 0.92 & $2.000 \mathrm{e}+02$ \\
\hline 13 & 1025 & 0.77 & $1.400 \mathrm{e}+03$ & 38 & 814 & 0.92 & $2.050 \mathrm{e}+02$ \\
\hline 14 & 1010 & 0.78 & $6.500 \mathrm{e}+02$ & 39 & 800 & 0.93 & $4.000 \mathrm{e}+02$ \\
\hline 15 & 1010 & 0.78 & $2.500 \mathrm{e}+02$ & 40 & 800 & 0.93 & $5.500 \mathrm{e}+02$ \\
\hline 16 & 1010 & 0.78 & $5.000 e+02$ & 41 & 780 & 0.95 & $6.300 \mathrm{e}+02$ \\
\hline 17 & 1010 & 0.78 & $4.500 e+02$ & 42 & 780 & 0.95 & $2.800 \mathrm{e}+02$ \\
\hline 18 & 1010 & 0.78 & $1.600 \mathrm{e}+02$ & 43 & 780 & 0.95 & $2.900 e+02$ \\
\hline 19 & 1010 & 0.78 & $1.700 \mathrm{e}+02$ & 44 & 780 & 0.95 & $5.000 \mathrm{e}+02$ \\
\hline 20 & 1010 & 0.78 & $1.000 \mathrm{e}+03$ & 45 & 780 & 0.95 & $3.300 \mathrm{e}+02$ \\
\hline 21 & $1010^{\circ}$ & 0.78 & $9.500 \mathrm{e}+02$ & 46 & 780 & 0.95 & $2.000 \mathrm{e}+02$ \\
\hline 22 & 1010 & 0.78 & $9.000 \mathrm{e}+02$ & 47 & 780 & 0.95 & $3.400 \mathrm{e}+02$ \\
\hline 23 & 1010 & 0.78 & $8.000 \mathrm{e}+02$ & 48 & 770 & 0.96 & $2.000 \mathrm{e}+02$ \\
\hline 24 & 1010 & 0.78 & $2.000 \mathrm{e}+02$ & 49 & 760 & 0.97 & $2.500 \mathrm{e}+02$ \\
\hline 25 & 1010 & 0.78 & $6.700 \mathrm{e}+02$ & 50 & 760 & 0.97 & $8.000 \mathrm{e}+02$ \\
\hline
\end{tabular}

*Notation $1.020 \mathrm{e}+02 \equiv 1.020 \times 10^{2}$. 
Table A2. Data for Dry Air Oxidation of Unirradiated Uranium for Temperature $>441{ }^{\circ} \mathrm{C}$. (Continued)

\begin{tabular}{|c|c|c|c|c|c|c|c||}
\hline $\begin{array}{c}\text { Data } \\
\text { Point }\end{array}$ & $\begin{array}{c}\text { Temperature } \\
\left({ }^{\circ} \mathrm{C}\right)\end{array}$ & $\begin{array}{c}\text { 0xidation } \\
\text { Rate* }\end{array}$ & $\begin{array}{c}\text { Data } \\
\left(0^{3} / \mathrm{T}\left(\mathrm{K}^{-1}\right)\right.\end{array}$ & $\begin{array}{c}\text { Temperature } \\
\left(\mathrm{mg} / \mathrm{cm}^{2} / \mathrm{hr}\right)\end{array}$ & $\begin{array}{c}\left.\text { Point }^{\circ} \mathrm{C}\right) \\
10^{3} / \mathrm{T}\left(\mathrm{K}^{-1}\right)\end{array}$ & $\begin{array}{c}\text { Oxidation } \\
\text { Rate } \\
\left(\mathrm{mg}^{*} \mathrm{~cm}^{2} / \mathrm{hr}\right)\end{array}$ \\
\hline 51 & 760 & 0.97 & $1.800 \mathrm{e}+02$ & 76 & 630 & 1.11 & $1.000 \mathrm{e}+03$ \\
\hline 52 & 760 & 0.97 & $1.900 \mathrm{e}+02$ & 77 & 630 & 1.11 & $2.000 \mathrm{e}+02$ \\
\hline 53 & 727 & 1.00 & $3.800 \mathrm{e}+02$ & 78 & 630 & 1.11 & $1.300 \mathrm{e}+02$ \\
\hline 54 & 710 & 1.02 & $2.200 \mathrm{e}+02$ & 79 & 630 & 1.11 & $4.500 \mathrm{e}+02$ \\
\hline 55 & 710 & 1.02 & $3.800 \mathrm{e}+02$ & 80 & 620 & 1.12 & $3.200 \mathrm{e}+02$ \\
\hline 56 & 710 & 1.02 & $2.000 \mathrm{e}+02$ & 81 & 620 & 1.12 & $1.800 \mathrm{e}+02$ \\
\hline 57 & 710 & 1.02 & $1.900 \mathrm{e}+02$ & 82 & 620 & 1.12 & $2.600 \mathrm{e}+02$ \\
\hline 58 & 700 & 1.03 & $8.000 \mathrm{e}+01$ & 83 & 620 & 1.12 & $1.600 \mathrm{e}+02$ \\
\hline 59 & 700 & 1.03 & $5.000 \mathrm{e}+02$ & 84 & 610 & 1.13 & $1.490 \mathrm{e}+02$ \\
\hline 60 & 660 & 1.07 & $2.000 \mathrm{e}+02$ & 85 & 610 & 1.13 & $1.850 \mathrm{e}+02$ \\
\hline 61 & 650 & 1.08 & $3.000 \mathrm{e}+02$ & 86 & 610 & 1.13 & $1.150 \mathrm{e}+02$ \\
\hline 62 & 650 & 1.08 & $1.600 \mathrm{e}+02$ & 87 & 610 & 1.13 & $1.050 \mathrm{e}+02$ \\
\hline 63 & 650 & 1.08 & $2.500 \mathrm{e}+02$ & 88 & 610 & 1.13 & $1.610 \mathrm{e}+02$ \\
\hline 64 & 650 & 1.08 & $1.050 \mathrm{e}+02$ & 89 & 610 & 1.13 & $1.730 \mathrm{e}+02$ \\
\hline 65 & 645 & 1.09 & $5.000 \mathrm{e}+02$ & 90 & 610 & 1.13 & $1.950 \mathrm{e}+02$ \\
\hline 66 & 645 & 1.09 & $3.500 \mathrm{e}+02$ & 91 & 610 & 1.13 & $1.370 \mathrm{e}+02$ \\
\hline 67 & 645 & 1.09 & $4.000 \mathrm{e}+02$ & 92 & 610 & 1.13 & $2.000 \mathrm{e}+02$ \\
\hline 68 & 645 & 1.09 & $2.100 \mathrm{e}+02$ & 93 & 600 & 1.15 & $2.100 \mathrm{e}+02$ \\
\hline 69 & 645 & 1.09 & $1.050 \mathrm{e}+02$ & 94 & 600 & 1.15 & $1.600 \mathrm{e}+02$ \\
\hline 70 & 645 & 1.09 & $2.000 \mathrm{e}+02$ & 95 & 600 & 1.15 & $1.800 \mathrm{e}+02$ \\
\hline 71 & 640 & 1.10 & $1.800 \mathrm{e}+02$ & 96 & 600 & 1.15 & $1.650 \mathrm{e}+02$ \\
\hline 72 & 640 & 1.10 & $4.000 \mathrm{e}+02$ & 97 & 575 & 1.18 & $9.500 \mathrm{e}+01$ \\
\hline 73 & 640 & 1.10 & $2.000 \mathrm{e}+02$ & 98 & 575 & 1.18 & $2.000 \mathrm{e}+02$ \\
\hline 74 & 640 & 1.10 & $3.500 \mathrm{e}+02$ & 99 & 575 & 1.18 & $8.000 \mathrm{e}+01$ \\
\hline 75 & 640 & 1.10 & $2.100 \mathrm{e}+02$ & 100 & 565 & 1.19 & $7.000 \mathrm{e}+01$ \\
\hline
\end{tabular}

*Notation $1.020 \mathrm{e}+02 \equiv 1.020 \times 10^{2}$. 
HNF-SD-SNF-CN-019, Rev, 0

Table A2. Data for Dry Air Oxidation of Unirradiated Uranium for Temperature $>441{ }^{\circ} \mathrm{C}$. (Continued)

\begin{tabular}{|c|c|c|c|c|c|c|c||}
\hline $\begin{array}{c}\text { Data } \\
\text { Point }\end{array}$ & $\begin{array}{c}\text { Temperature } \\
\left({ }^{\circ} \mathrm{C}\right)\end{array}$ & $10^{3} / \mathrm{T}\left(\mathrm{K}^{-1}\right)$ & $\begin{array}{c}\text { 0xidation } \\
\text { Rate } e^{*} \\
\left(\mathrm{mg} / \mathrm{cm}^{2} / \mathrm{hr}\right)\end{array}$ & $\begin{array}{c}\text { Data } \\
\text { Point }\end{array}$ & $\begin{array}{c}\text { Temperature } \\
\left({ }^{\circ} \mathrm{C}\right)\end{array}$ & $10^{3} / \mathrm{T}\left(\mathrm{K}^{-1}\right)$ & $\begin{array}{c}\text { 0xidation } \\
\text { Rate* } \\
\left(\mathrm{mg} / \mathrm{cm}^{2} / \mathrm{hr}\right)\end{array}$ \\
\hline 101 & 560 & 1.20 & $9.500 \mathrm{e}+01$ & 119 & 495 & 1.30 & $5.500 \mathrm{e}+01$ \\
\hline 102 & 560 & 1.20 & $8.000 \mathrm{e}+01$ & 120 & 495 & 1.30 & $6.500 \mathrm{e}+01$ \\
\hline 103 & 560 & 1.20 & $1.050 \mathrm{e}+02$ & 121 & 495 & 1.30 & $6.700 \mathrm{e}+01$ \\
\hline 104 & 560 & 1.20 & $1.400 \mathrm{e}+02$ & 122 & 495 & 1.30 & $1.800 \mathrm{e}+02$ \\
\hline 105 & 560 & 1.20 & $2.000 \mathrm{e}+02$ & 123 & 495 & 1.30 & $9.000 \mathrm{e}+02$ \\
\hline 106 & 560 & 1.20 & $2.500 \mathrm{e}+02$ & 124 & 490 & 1.31 & $8.000 \mathrm{e}+01$ \\
\hline 107 & 545 & 1.22 & $9.500 \mathrm{e}+01$ & 125 & 490 & 1.31 & $9.000 \mathrm{e}+01$ \\
\hline 108 & 545 & 1.22 & $6.000 \mathrm{e}+01$ & 126 & 490 & 1.31 & $1.050 \mathrm{e}+02$ \\
\hline 109 & 535 & 1.24 & $2.500 \mathrm{e}+02$ & 127 & 490 & 1.31 & $1.000 \mathrm{e}+02$ \\
\hline 110 & 535 & 1.24 & $1.030 \mathrm{e}+02$ & 128 & 480 & 1.33 & $1.000 \mathrm{e}+02$ \\
\hline 111 & 510 & 1.28 & $1.100 \mathrm{e}+02$ & 129 & 450 & 1.38 & $5.000 \mathrm{e}+01$ \\
\hline 112 & 510 & 1.28 & $8.000 \mathrm{e}+01$ & 130 & 450 & 1.38 & $1.300 \mathrm{e}+02$ \\
\hline 113 & 500 & 1.29 & $2.000 \mathrm{e}+02$ & 131 & 450 & 1.38 & $1.400 \mathrm{e}+02$ \\
\hline 114 & 500 & 1.29 & $9.000 \mathrm{e}+01$ & 132 & 450 & 1.38 & $6.000 \mathrm{e}+01$ \\
\hline 115 & 500 & 1.29 & $1.000 \mathrm{e}+02$ & 133 & 445 & 1.39 & $1.400 \mathrm{e}+02$ \\
\hline 116 & 500 & 1.29 & $6.500 \mathrm{e}+01$ & 134 & 445 & 1.39 & $1.050 \mathrm{e}+02$ \\
\hline 117 & 495 & 1.30 & $6.000 \mathrm{e}+01$ & 135 & 445 & 1.39 & $5.000 \mathrm{e}+01$ \\
\hline 118 & 495 & 1.30 & $8.000 \mathrm{e}+01$ & & & & \\
\hline & & & & & & & \\
\hline
\end{tabular}

*Notation $1.020 \mathrm{e}+02 \equiv 1.020 \times 10^{2}$. 
HNF-SD-SNF-CN-019, Rev. 0

\section{APPENDIX B \\ SUPPLEMENTAL FRENCH AND ENGLISH DATA FOR DRY AIR OXIDATION OF URANIUM}

Supplemental data for dry air oxidation of unirradiated uranium from the French and English is 1isted in Table BI (Bennett et al. 1975; Paidassi et at: 1979). Limited data on the behavior of irradiated uranium is listed in Table B2.

\section{References}

Bennett, M. J., B. L. Myatt, D. R. U. Silvester, and J. E. Antill, 1975, "The Oxidation Behavior of Uranium in Air at $50-300^{\circ} \mathrm{C}$, Journal of Nuclear Materials, Vol. 57, pp. 221-236.

Paidassi, J. R. Dominget, and J. Dixmier, 1979, Comportement en presence d'air ou d'eau de l'uranium et de combustibles metalligues a base d'uranium irradie ou non, CEA-SECMLG-11079, Unpublished Work, Atomic Energy Commission, Paris, France. 
Table B1. Supplemental French Data for Dry Air Oxidation of Unirradiated Uranium.

\begin{tabular}{|c|c|c|c|c|}
\hline $\begin{array}{l}\text { Data } \\
\text { Point }\end{array}$ & $\begin{array}{c}\text { Temperature } \\
\left({ }^{\circ} \mathrm{C}\right)\end{array}$ & $10^{3} / \top\left(K^{-1}\right)$ & $\begin{array}{c}\text { Rate } \\
\left(\mathrm{mg} / \mathrm{cm}^{2} / \mathrm{hr}\right)\end{array}$ & Reference \\
\hline 1 & 100 & 2.68 & $5.2 \times 10^{-3}$ & Paidassi 1979 \\
\hline 2 & 150 & 2.36 & $1.1 \times 10^{-2}$ & Paidassi 1979 \\
\hline 3 & 200 & 2.11 & 0.59 & Paidassi 1979 \\
\hline 4 & 200 & 2.11 & 0.30 & Paidassi 1979 \\
\hline 5 & 200 & 2.11 & 0.19 & Paidassi 1979 \\
\hline 6 & 200 & 2.11 & 0.16 & Paidassi 1979 \\
\hline 7 & 250 & 1.91 & 0.48 & Paidassi 1979 \\
\hline 8 & 300 & 1.75 & 3.08 & Paidassi 1979 \\
\hline 9 & 300 & 1.75 & 2.29 & Paidassi 1979 \\
\hline 10 & 300 & 1.75 & 2.78 & Paidassi 1979 \\
\hline 11 & 400 & 1.49 & 151.00 & Paidassi 1979 \\
\hline 12 & 500 & 1.29 & 151.70 & Paidassi 1979 \\
\hline
\end{tabular}


Table B2. Supplemental French and English Data on oxidation of Irradiated Uranium in Dry Air.

\begin{tabular}{|c|c|c|c|c|}
\hline $\begin{array}{l}\text { Data } \\
\text { Point } \\
\end{array}$ & $\begin{array}{c}\text { Temperature } \\
\left({ }^{\circ} \mathrm{C}\right)\end{array}$ & $10^{3} / \mathrm{T}\left(\mathrm{K}^{-1}\right)$ & $\begin{array}{c}\text { Rate } \\
\left(\mathrm{mg} / \mathrm{cm}^{2} / \mathrm{hr}\right)\end{array}$ & Reference \\
\hline \multicolumn{5}{|c|}{ Less than $12 \%$ Fuel Swelling } \\
\hline 1 & 150 & 2.36 & $4.90 \times 10^{-3}$ & Paidassi 1979 \\
\hline 2 & 200 & 2.11 & 0.43 & Paidassi 1979 \\
\hline \multicolumn{5}{|c|}{ Greater than $12 \%$ Fuel Swelling } \\
\hline 1 & 100 & 2.68 & $2.80 \times 10^{-3}$ & Bennett 1975 \\
\hline 2 & 200 & 2.11 & 1.13 & Paidassi 1979 \\
\hline 3 & 200 & 2.11 & 0.87 & Paidassi 1979 \\
\hline 4 & 200 & 2.11 & 1.12 & Paidassi 1979 \\
\hline 5 & 250 & 1.91 & 4.80 & Paidassi 1979 \\
\hline 6 & 300 & 1.75 & 231.70 & Paidassi 1979 \\
\hline 7 & 300 & 1.75 & 128.70 & Paidassi 1979 \\
\hline 8 & 300 & 1.75 & 146.80 & Paidassi 1979 \\
\hline 9 & 400 & 1.49 & 131.60 & Paidassi 1979 \\
\hline 10 & 500 & 1.29 & 143.90 & Paidassi 1979 \\
\hline 11 & 500 & 1.29 & 102.30 & Paidassi 1979 \\
\hline
\end{tabular}


HNF-SD-SNF-CN-019, Rev, 0

This page intentionally left blank. 
HNF-SD-SNF-CN-019, Rev, 0

APPENDIX C

K BASIN FUEL DATA FOR DRY AIR OXIDATION

The laboratory measurements of oxidation of $\mathrm{K}$ Basin fuel material in dry air are summarized in Table Cl (Abrefah et al., 1998).

\section{References}

Abrefah, J., H. C. Buchanan, W. M. Gerry, W. J. Gray, and S. C. Marschman, 1998, Dry Air Oxidation Kinetics of K Basin Spent Nuclear Fuel,

PNNL-11786, Pacific Northwest National Laboratory, Richiand, Washington. 
HNF-SD-SNF-CN-019; Rev. 0

Table C1. 0xidation Rate of $\mathrm{K}$ Basin Spent Nuclear Fuel in Dry Air.

\begin{tabular}{||l|c|c|c|c|c||}
\hline $\begin{array}{c}\text { TGA } \\
\text { Run }\end{array}$ & $\begin{array}{c}\text { Sample } \\
\text { Number }\end{array}$ & $\begin{array}{c}\text { Sample } \\
\text { Weight } \\
(\mathrm{g})\end{array}$ & $\begin{array}{c}\text { Test } \\
\text { Temperature } \\
\left({ }^{\circ} \mathrm{C}\right)\end{array}$ & $\begin{array}{c}\text { Sample } \\
\text { Geometric } \\
\text { Surface Area } \\
\left(\mathrm{cm}^{2}\right)\end{array}$ & $\begin{array}{c}\text { Oxidation } \\
\text { Rate } \\
\left(\mathrm{mg} / \mathrm{cm}^{2} / \mathrm{hr}\right)\end{array}$ \\
\hline \hline $5 \mathrm{l}$ & $10-S 3-A 2$ & 6.02 & 69 & 2.41 & 0.0278 \\
\hline $49 \mathrm{a}$ & $10-S 3-A 3$ & 6.03 & 90 & 2.41 & 0.00660 \\
\hline $49 \mathrm{~b}$ & $10-S 3-A 4$ & 5.52 & 124 & 2.39 & 0.182 \\
\hline $19 \mathrm{a}$ & $10-S 3-F 3$ & 7.20 & 200 & 2.56 & 0.576 \\
\hline 47 & $5-S I A-E 4 E$ & 5.22 & 225 & 2.29 & 1.26 \\
\hline 20 & $10-S 3-F 4$ & 7.14 & 250 & 2.50 & 2.62 \\
\hline 48 & $5-S I A-E 4 D$ & 4.57 & 275 & 2.62 & 2.47 \\
\hline
\end{tabular}




\section{APPENDIX D}

\section{NON-LINEAR OXIDATION}

A paralinear model by Pearce and Kay (1987) predicts the oxidation of clean uranium surfaces in dry air. The model was developed using test data in the temperature range $105^{\circ} \mathrm{C}$ to $325^{\circ} \mathrm{C}$ and takes the form

$$
W=k_{p} \times t^{1 / 2}+k_{l} \times t
$$

where:

$W$ is weight gain, $t$ is time, and $k_{p}$ and $k_{l}$ are the parabolic and Tinear rate constants, respectively.

The rate constant values are calculated using the following rate law equations:

$$
\log k_{p}=3.679-1922 / T
$$

and

$$
\log k_{l}=8.946-4638 / T
$$

with $k_{p}$ expressed in units of $\mathrm{mg}$ weight gain $\mathrm{cm}^{2} / \mathrm{hr}$ and $k_{1}$ in units of $\mathrm{mg} / \mathrm{cm}^{2} / \mathrm{hr}$. T is the temperature in degrees Kelvin. A similar paralinear model has been reported by Colmenaries (1984) using different rate 1 aw equations.

Weight gain curves for oxidation of uranium in dry air at $90{ }^{\circ} \mathrm{C}$ and $200{ }^{\circ} \mathrm{C}$ using Equations (D1) (D2) and (D3) are shown on Figure D1. The time of exposure ( 8 hours) is similar to that expected for Cold Vacuum Drying (CVD) of an MCO containing typical K Basin SNF. Average linear oxidation between 3 and 8 hours is shown on the plots. The slope of this pseudo-linear oxidation is compared to the linear. constant $\left(k_{L}\right)$ for the oxidation plot (see Figure $\mathrm{D1}$ ). Note that the ratio of the pseudo-linear oxidation rate to $\mathrm{K}_{\mathrm{l}}$ is substantially higher at $70^{\circ} \mathrm{C}$ than at $200^{\circ} \mathrm{C}$. If only the 7 inear rate represented by the linear oxidation from 3 to 8 hours were used in a calculation of oxidation for the clean uranium represented in these plots, substantial oxidation would not be calculated for the first 2 hours of exposure.

$K$ Basin SNF samples have been tested in dry air and the results were reported by Abrefah, et aT. (1998) and are Tisted in Appendix C of this document. The surfaces of the samples used in the tests were as cut, that is they were not cleaned of oxide that may have existed from the cutting operations or exposure to ambient air after cutting. Thus, a thin, unknown thickness of oxide covered the test surfaces at the initiation of the oxidation tests. This oxide coating was certainly much less than that of a long exposed surface of a failed fuel element stored in the $\mathrm{K}$ Basin water for the typical 10 to 20 years. It may not, however, be very different than 
freshly exposed surfaces resulting from preparations of the fuel for loading into an MCO. If it becomes necessary for the Spent Nuclear Fuel Project to consider oxidation of relatively unoxidized surfaces, a method for accomplishing this will be needed. One possible strategy is outlined in the following discussion.

Figure D2 shows the data from SNF test runs at $90{ }^{\circ} \mathrm{C}$ and $124{ }^{\circ} \mathrm{C}$. These oxidation curves show non-linear oxidation in the first few hours of the test. The Tinear oxidation rates from Appendix $C$ are shown on the plots as bold lines fit to the later portion of the curves. A line extends from the origin and intersects the bold 1 ine at 2 hours. This represents the mean linear oxidation rate between time zero and 2 hours exposure. Each of the SNF data curves were evaluated in this way with the initial-1inear rate constants $\left(k_{i}\right)$ and the final-linear rate constants $\left(k_{f}\right)$ plotted on Figure D3. Linear regression analyses of $\log$ (rate) versus inverse temperature (1/T) were

performed to derive equations for the rate constants. Equations for the upper and lower bounds were determined using the mean of the $95 \%$ prediction intervals. These equations are applicable only at temperature below $287{ }^{\circ} \mathrm{C}$ $(560 \mathrm{~K})$. Above $560 \mathrm{~K}, \mathrm{k}_{\mathrm{i}} \cong \mathrm{k}_{\mathrm{f}}$, and the one step 1inear oxidation equations given in the main body of this document may be used for clean surface without significant penalty.

\section{For Process Calculations}

$\log k_{i}=2.235-935.5 / T$ for $t \leq 2 \mathrm{hr}$ and $\mathrm{T} \leq 560 \mathrm{~K}$

$\log k_{f}=4.451-2177 / T$ for $t \geq 2 \mathrm{hr}$

$k_{i}=k_{f}$ at $T>560 K$

Upper Bound for Safety Basis

$\log k_{i}=2.985-935.5 / T$ for $t \leq 2 \mathrm{hr}$ and $T \leq 494 \mathrm{~K}$

$k_{i}=k_{f}$ at $T>494 K$

$\log k_{f}=5.499-2177 / T$ for $t \geq 2 \mathrm{hr}$

\section{Lower Bound for Safety Basis}

$\log k_{i}=1.485-935.5 / T$ for $t \leq 2 \mathrm{hr}$ and $T \leq 560 \mathrm{~K}$

$\log k_{f}=3.402-2177 / T$ for $t \geq 2 \mathrm{hr}$

where:

$k$ is rate of weight gain in $\mathrm{mg} / \mathrm{cm}^{2} / \mathrm{hr}$, $t$ is time in hours and $T$ is temperature in degrees KeTvin. 


\section{References}

Abrefah, J., H. C. Buchanan, W. M. Gerry, W. J. Gray, and S. C. Marschman, 1998, Dry Air Oxidation Kinetics of K Basin Spent Nuclear Fuel,

PNNL-11786, Pacific Northwest National Laboratory, Richland, Washington.

Colmenares, C. A., 1984, "Oxidation of Mechanisms and Cataiytic Properties of the Actinides," Progress in Solid State Chemistry, Vol. 15, pp. 257-364.

Pearce, R. J., and P. Kay, 1987, The Reaction of Uranium in the $\mathrm{U}_{-} \mathrm{O}_{2}-\mathrm{H}_{2} \mathrm{O}$ and $U-\mathrm{H}_{2} \mathrm{O}$ Systems, TPRD/B/0954/R87, Central Electric Generating Board, Berkeley Nuclear Laboratories, United Kingdom. 
HNF-SD-SNF-CN-019, Rev. 0

Figure D1. Oxidation of Uranium in Dry Air at $70{ }^{\circ} \mathrm{C}$ and $200{ }^{\circ} \mathrm{C}$ as Predicted by Pearce and Kay (1987).
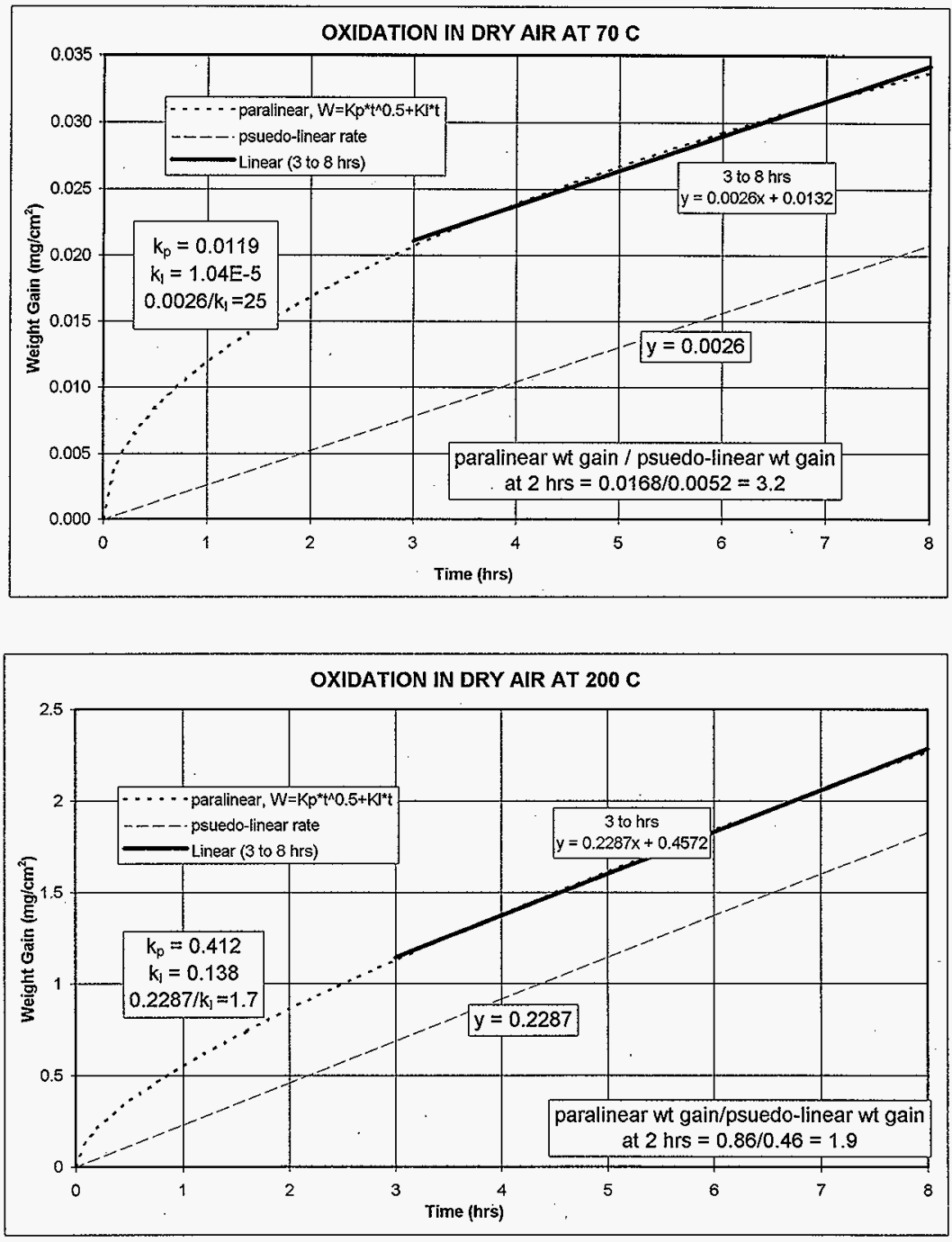
Figure D2. Evaluation of 0xidation Data from $K$ Basin Fue1 Tests at $90{ }^{\circ} \mathrm{C}$ and $124{ }^{\circ} \mathrm{C}$ for Two-Step Linear Oxi idation Rate Data.
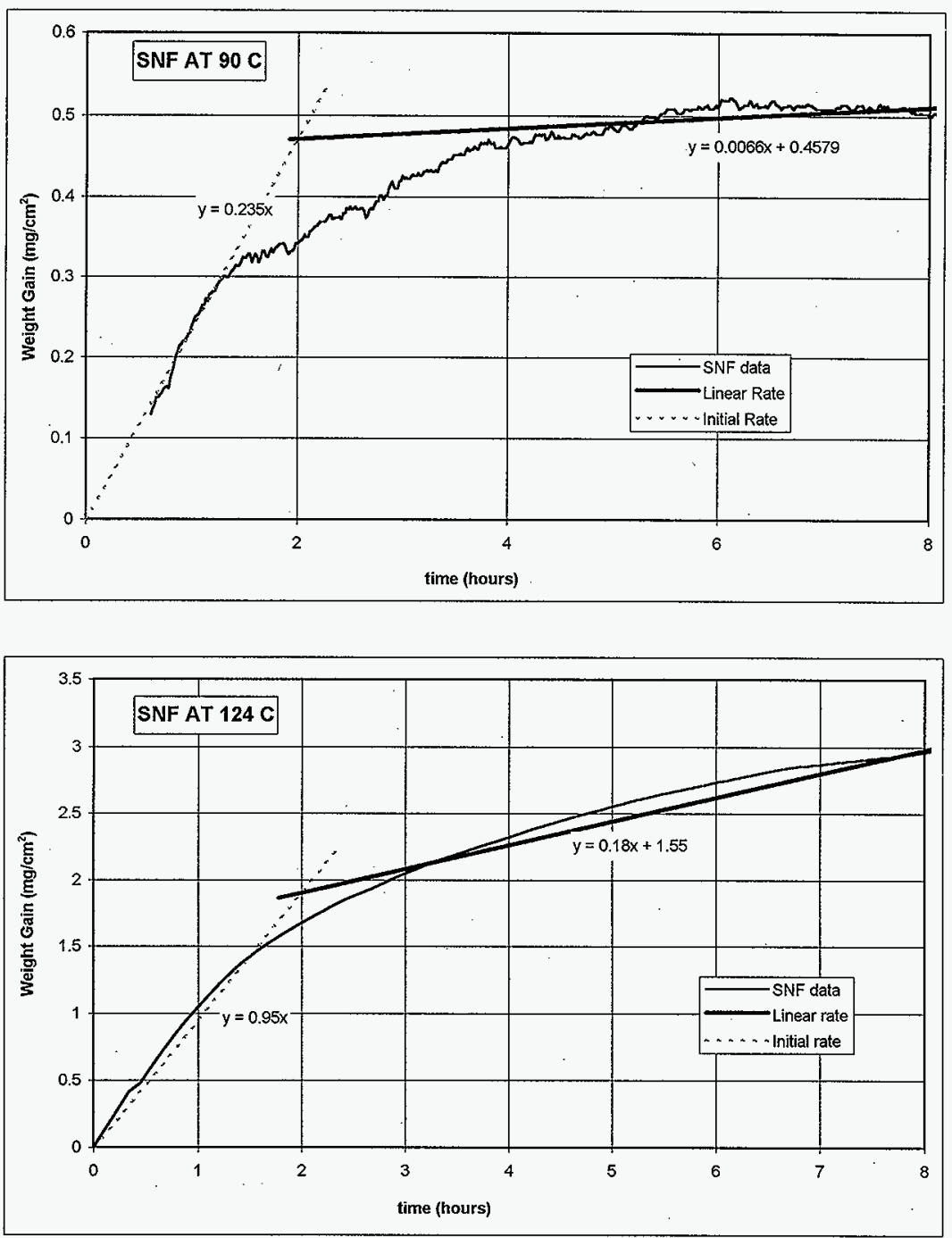
Figure D3. Arrhenius P1ot of Two-Step Linear Oxidation Rate Data from $K$ Basin Fue? Tests.

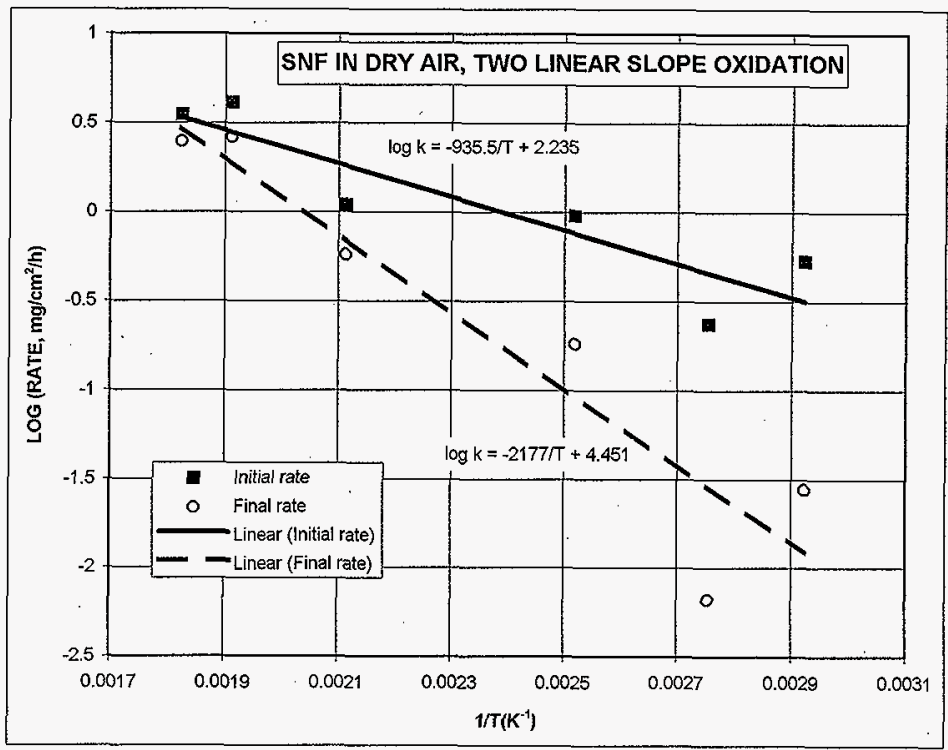




\section{DISTRIBUTION SHEET}

\begin{tabular}{|c|c|c|c|c|c|}
\hline \multirow{2}{*}{$\begin{array}{l}\text { To } \\
\text { Distribution }\end{array}$} & \multirow{2}{*}{\multicolumn{3}{|c|}{$\begin{array}{l}\text { From } \\
\text { SNF Characterization Project }\end{array}$}} & \multicolumn{2}{|l|}{ Page 1 of 2} \\
\hline & & & & \multicolumn{2}{|c|}{ Date April 1998} \\
\hline \multicolumn{4}{|l|}{ Project Title/Work Order } & \multicolumn{2}{|c|}{ EDT No. 620809} \\
\hline \multicolumn{4}{|c|}{$\begin{array}{l}\text { Reaction Rate Constant for Dry Air 0xidation of } K \text { Basin Fue } 1 \\
\text { HNF-SD-SNF-CN-019, Rev. } 0\end{array}$} & \multicolumn{2}{|l|}{ ECN No. } \\
\hline Name & MSIN & $\begin{array}{l}\text { Text } \\
\text { With All } \\
\text { Attach. }\end{array}$ & Text Only & $\begin{array}{l}\text { Attach./ } \\
\text { Appendix } \\
\text { Only }\end{array}$ & $\begin{array}{l}\text { EDT/ECN } \\
\text { Only }\end{array}$ \\
\hline
\end{tabular}

\section{Fluor Daniel Hanford, Inc.}

R. L. McCormack

R3-11 $\quad X$

ARES

J. P. Sederberg

R3-86 $\quad X$

B\&W Hanford Company

T. D. Cooper

T5-12 . $\quad \mathrm{X}$

B\&W Protec, Inc.

T. L. Weish

$\mathrm{T} 4-40$

$x$

COGEMA
A. L. Pajunen
R3-86
$x$

Duke Engineering \& Services Hanford, Inc.
R. B. Baker
D. E. Ba11
D. W. Bergmann
L. D. Bruggeman
D. R. Duncan (3)
J. R. Frederickson
L. H. Goldman
L. A. Lawrence
B. J. Makenas
R. P. Omberg
J. Perez-Carter
A. L. Pitner
A. M. Segrest
D. W. Smith
J. A. Swenson
D. J. Trimble
J. H. Wicks

HO-40

R3-86

$\times 3-79$

HO- 40

R3-86

R3-86

R3-86

HO- 40

HO- 40

HO- 40

HO- 40

HO- 40

R3-1I

R3-11

R3-11

$\mathrm{HO}-40$

$\times 3-78$

SNF Project Files

R3-11

$x$
$x$
$x$
$x$
$x$
$x$
$x$
$x$
$x$
$x$
$x$
$x$
$x$
$x$
$x$
$x$
$x$
$x$

Fauske \& Associates

M. G. Plys

S7-14

$x$ 


\section{DISTRIBUTION SHEET}

\begin{tabular}{|c|c|c|c|c|c|}
\hline \multirow{2}{*}{$\begin{array}{l}\text { To } \\
\text { Distribution }\end{array}$} & \multirow{2}{*}{\multicolumn{3}{|c|}{$\begin{array}{l}\text { From } \\
\text { SNF Characterization Project }\end{array}$}} & \multicolumn{2}{|l|}{ Page 2 of 2} \\
\hline & & & & \multicolumn{2}{|c|}{ Date Apri1 1998} \\
\hline \multicolumn{4}{|c|}{ Project Title/Work Order } & \multicolumn{2}{|c|}{ EDT No. 620809} \\
\hline \multicolumn{4}{|c|}{$\begin{array}{l}\text { Reaction Rate Constant for Dry Air Oxidation of K Basin Fue } 1 \\
\text { HNF-SD-SNF-CN-019, Rev. } 0\end{array}$} & \multicolumn{2}{|l|}{ ECN No. } \\
\hline Name & MSIN & $\begin{array}{l}\text { Text } \\
\text { With All } \\
\text { Attach. }\end{array}$ & Text Only & $\begin{array}{l}\text { Attach./ } \\
\text { Appendix } \\
\text { Only }\end{array}$ & $\begin{array}{l}\text { EDT/ECN } \\
\text { Only }\end{array}$ \\
\hline
\end{tabular}

Fluor Daniel Northwest

R. D. Crowe

Lockheed Martin Services, Inc.
R3-26 $\quad X$

B1-07 $X$

Numatec Hanford Corporation

G. P. Chevrier

T. A. Flament

C. R. Miska

C. Pili-Vincens

J. P. Sloughter
H5-25

H5-25

R3-86

R3-26

H5- 49
Pacific Northwest National Laboratory

J. Abrefah

S. C. Marschman

P7-27

P.7-27 $x$
$x$
$x$
$x$
$x$

. $x$
$X$

Denartment of Fnergy

Richland Operations office

P. G. Loscoe

J. Shuen

S7-41

$57-41$ 